\title{
The Debate on NATO Expansion
}

Eunika Katarzyna Frydrych ${ }^{*}$

\section{The Nature of NATO Enlargement: Alliance Theory}

This essay addresses the general rationale for creating and enlarging alliances. It presents a definition of alliance; explores the reasons for forming alliances; and examines the value that this type of arrangement adds. In particular, this paper will attempt a deeper analysis of the question why alliances choose to enlarge.

NATO is a classic example of an alliance. The organization was launched by Western countries to ensure the security of its member states, which in practice meant deterring the threat posed by the Soviet Union and the states affiliated with it in the Warsaw Pact. It is a multilateral alliance based on a formal agreement- the Washington Treaty (1949) — that provides security guarantees for every member state. In addition, it has been a defensive alliance that aims at maintaining the sovereignty and freedom of its members. However, what distinguishes NATO from alliances of the past is its subordination to the United Nations Charter. ${ }^{1}$

One of the widely-accepted of an alliance is the one developed by Stephen M. Walt. He characterizes an alliance as "a formal or informal arrangement for security cooperation between two or more sovereign states."2 There is another definition of an alliance that characterizes the institution "as a treaty-bound group of states that applies military means to security problems." ${ }^{3}$ Taken together, these descriptions offer quite a narrow definition, as they perceive alliances as purely military phenomena, and do not take into account the existence of political alliances. With reference to the discourse on NATO, however, this definition seems to be suitable.

The question of the formation of alliances is one of the principal areas of exploration of the neorealist school of thought in international relations. According to scholars representing this school, "the systemic structure, structural polarity and systemic anarchy, determine the formation of alliances. In particular, the anarchy characteristic of

The author is a Senior Expert in the International Security Policy Department in the Polish Ministry of National Defense in Warsaw.

1 Richard H. Heindel, Thorsten V. Kalijarvi, and Francis O. Wilcox, "The North Atlantic Treaty in the United States Senate,” The American Journal of International Law 43 (1949): 663.

2 Stephen M. Walt, The Origins of Alliances (Ithaca, NY: Cornell University Press, 1990), 12.

3 Mark Smith, NATO Enlargement during the Cold War: Strategy and System in the Western Alliance (Houndmills, U.K.: Palgrave, 2000), 3. 
the international system leads states to accord primacy to their security." 4 After the Second World War, the question of ensuring security was of utmost importance for Western countries. The growing politico-military confrontation with the Eastern Bloc and the threat posed by the Soviet Union and its satellite states prompted the formation of the Alliance in 1949. Western nations were afraid that they would not be able to guarantee themselves a level of safety sufficient to allow them to function in such a demanding security environment and rebuild their economies after the Second World War. Thus, we can perceive the creation of NATO as a natural response to the security concerns and security environment in existence immediately following World War II.

Some of the key questions to address are what, exactly, are the functions of alliances? What are the most important factors prompting the creation of this kind of arrangement? And what kind of benefits can be gained by individual states from participating in alliances? As Martin Wight argues, "The function of an alliance is to reinforce the security of the allies or to promote their interests in the external world. States incapable of facing unilaterally a stronger enemy decide to cooperate with other states in the same situation in order to increase their security by massing their capabilities against a common enemy." George Liska argues in the same vein that "alliances help to direct the military, technological, economic, and sociocultural capabilities and attributes of a particular state to the purposes of a larger collective body." However, he identifies one very important argument. According to him, "alliances may also be formed in an effort to prevent states from conflicting amongst themselves and thus to channel the respective energies and interest of states toward positive collective goals. Alliances can thus provide stability and protection, ameliorate intra-alliance disputes and tensions, seek to reduce collective costs, and provide predictability for investment, if not serve to open markets."

From the above paragraph one can conclude that there are two main reasons why alliances are launched:

1. External, to ensure safety from common enemies by gathering a group of states together in a way that enables them to combine their potential and strength

2. Internal, to help mitigate tensions and resolve disputes that exist between countries within an alliance.

4 Wolfango Piccoli, “Alliance Theory: The Case of Turkey and Israel,” CIAO Working Papers (August 1999); available at www.ciaonet.org/wps/pic01/. It is the view of neorealists that "anarchy" means a lack of hierarchy in international relations, because states-as the main actors in the international system — do not recognize any authority above them. Philippo Andreatta, “Theory and the European Union's International Relations,” in International Relations and the European Union, eds. Christopher Hill and Michael Smith (Oxford: Oxford University Press, 2005), 23.

6 Quoted in Carl C. Hodge, NATO for a New Century: Atlanticism and European Security (Westport, CT: Praeger Publishers, 2002), 25. 
The first reason is of primary importance. The basic motivation is to create an alliance in order to pool the military capacities of all its member states, and in consequence to strengthen the collective possibilities of self-defense. In the case of NATO, the alliance was created in response to a robust threat posed by the Soviet Union. Whereas the second, internal motivation can be seen as being of secondary importance, it obviously reinforces the strength and effectiveness of an alliance's arrangements (this is also the case when we analyze the formation of NATO). This institution has aimed at preventing aggression from a third party, but the member states have also sought to integrate themselves within the organization and ensure good relations and peace between one another, e.g., between the Federal Republic of Germany and its former adversaries from the Second World War, especially France. Nevertheless, the practice occasionally met with less success, as in the case of the interactions between Turkey and Greece.

The issue of alliances is directly connected with the theory of the balance of power, which is also known as "balance of threat theory." According to this theory, "states form alliances in order to prevent stronger powers from dominating them." 7 As Stephen M. Walt writes, "states form alliances primarily to balance against threats. Threats, in turn, are functions of power, geographic proximity, offensive capabilities, and perceived intentions."

The creation of NATO can be seen as an effort to influence the balance of power. The aim was to launch an organization that would be able to counterbalance and deter the threat posed by the Eastern Bloc. The Alliance enabled its members to combine at its inception the military capabilities of twelve states (and then of other members) around the dominant power, the United States. It has been a special kind of arrangement, providing security guarantees via Article 5 of the Washington Treaty. ${ }^{9}$ It obviously increased the perceived and real sense of security on the part of all of its member states. Not without importance was the additional aim to reinforce transatlantic relations, political dialogue, and military cooperation between two North American nations and ten European ones.

There is one crucial question, however: What happens when a threat-the very threat that brought about the creation of an alliance and strengthened the coherence between partners-disappears? Some theorists of international relations, especially representatives of the neorealist school of thought, argue that the original threat's disappearance undermines the rationale for the existence of the alliance. ${ }^{10}$ At the beginning of the 1990s, immediately after the collapse of the Soviet Union, two representatives of the neorealist school of thought, Kenneth N. Waltz and John J. Mearsheimer,

Walt, The Origins of Alliances, x, 18.

8 Ibid., vi.

9 To get more information on collective security arrangements, see Charles L. Glaser, "Why NATO Is Still Best: Future Security Arrangements for Europe,” International Security 18:1 (1993): 26-29.

10 Compare with James M. Goldgeier, Not Whether But When: The U.S. Decision to Enlarge NATO (Washington, D.C.: Brookings Institute Press, 1999), 3. 
expressed their opinion that, "without an external enemy (i.e., the Soviet Union) the Alliance would lose its reason for existence."11 Waltz further stated "it is the Soviet threat that provides the glue that holds NATO together. Take away that offensive threat and the United States is likely to abandon the Continent." ${ }^{\text {"12 }}$ This is why many expected the organization to "wither away or, at best, to stagnate and decline in importance."13

Neorealists would commend the analysis of Bruno Tertrais, who scrutinized a few cases of multilateral formal alliances. He observed that "permanent multilateral alliances appear increasingly to belong to the past," noting that many of them collapsed. Tertrais continues by pointing out that "permanent multilateral alliances have ... proven difficult to maintain because their members have chosen to opt out when disagreeing ... and because diminished threats have made their cohesion harder to maintain."14

So, how one can apply the predictions and conclusions described above to the case of NATO's development after the end of the Cold War? It is apparent that these neore-

11 Both authors cited in Ryan C. Hendrickson, “The Miscalculation of NATO’s Death,” Parameters 37:1 (2007): 100.

12 Ibid. For more, see John J. Mearsheimer, "Back to the Future: Instability in Europe After the Cold War," International Security 15:1 (1990): 5-56; Kenneth N. Waltz, "The Emerging Structure of International Politics," International Security 18:2 (1993): 44-79; and Robert W. Rauchhaus, "Marching NATO Eastward: Can International Relations Theory Keep Pace?” in Explaining NATO Enlargement, ed. Robert W. Rauchhaus (London: Frank Cass Publishers, 2001), 11-13. The neorealist view of the development of NATO is pessimistic. Neoliberal institutionalists (such as Robert O. Keohane) represent another understanding. They are more optimistic about the Alliance than the neorealists. They maintain that "NATO does and will continue to perform valuable functions" (Paul Papayoanou, "Intra-Alliance Bargaining and U.S. Bosnia Policy,” Journal of Conflict Resolution 41:1 (1997): 93). They argue that "first, unlike most military alliances, NATO is highly institutionalized. It provides members with well-defined rules and joint decision-making procedure, and requires them to participate in a unified military command structure. Second, NATO is about much more than just coordinating military policy to deter and defend against a common enemy. From its inception, NATO has had the broader goal of enhancing its members' security, which includes promoting stable civil-military relations within member states as well as preventing security competition between them" (Rauchhaus, "Marching NATO Eastward," 13-14). To compare these analyses, see Rauchhaus' description of the views of representatives of organization theory and constructivism (Rauchhaus, 15-19).

13 Rauchhaus, "Marching NATO Eastward," 3.

14 Bruno Tertrais, "The Changing Nature of Military Alliances," The Washington Quarterly 27:2 (2004): 135-50; quoted at 139. Tertrais refers, for example, to such formal multilateral alliances as the Southeast Asia Treaty Organization (SEATO) between the U.S., the UK and the countries of Southeast Asia and the South Pacific which existed from 1954 to 1977; the Central Treaty Organization (CENTO) between Iraq, Iran, Turkey, Pakistan, and the U.K., which lasted from 1955 to 1979; the Australia, New Zealand, United States Security Treaty (ANZUS) established in 1951, which in 1986 "became de facto a bilateral alliance as Washington decided to suspend its obligations toward Wellington after New Zealand refused to allow nuclear-armed or nuclear-propelled U.S. ships to call on its ports” (Tertrais, 139). 
alist predictions have not become a reality, and the Alliance has not collapsed. Additionally, many analysts have assessed NATO as a thriving institution. The simple explanation of this phenomenon is also provided by neorealist scholars, who argue simply that "NATO is still a better arrangement than any other alternative." 15 The second element of the answer to the question of why NATO still exists and performs its functions is the fact that the Alliance has undergone a process of transformation after the end of the Cold War. NATO, "created as an organization dedicated to the collective defense of its members, ... transformed itself in the 1990s, expanding its mission to include conflict prevention and conflict management throughout Europe, including beyond the boundaries of the NATO treaty area."16 As Tertrais argues, "unlike other multinational alliances, NATO was able to evolve after the threat against which it was created disappeared, therefore allowing it to maintain its position as the dominant security arrangement on the continent."17 This view represents very well the statement made by then-Assistant Secretary of State for European and Canadian Affairs in the U.S. State Department, Richard Holbrooke, who asserted in 1995: "The threat is gone. ... I believe if we left NATO unchanged in its present configuration, it would become irrelevant." 18

In this regard, the enlargement of the Alliance can be seen as one of the elements of its transformation after the end of the Cold War. It was the Alliance's response to the new security environment and its contribution to the stabilization of the Euro-Atlantic area as a whole. It has been an attempt to define its own identity afresh.

If NATO's enlargement is one of the key elements of its transformation, one should examine the question of why the organization expanded. This part of this article will try to account for this process from the perspective of the theory of international relations. In general,

NATO enlargement is difficult to explain on the basis of system-level, rationalist alliance theory which starts from the assumption of states instrumentally pursuing their egoistic security and power interests in the international system. By contrast, a sociological institutionalist theory, which conceives international organizations as agencies of international communities of values and norms, accounts for enlargement in general, and the selection of candidates in particular: NATO admitted states that have come to share

15 Marco Cesa, “From Hegemony to Ambivalence: NATO’s Transformation and European Stability,” fellowship report submitted to the NATO Office of Information and the Press (30 June 1999), 17; available at www.nato.int/acad/fellow/97-99/cesa.pdf.

Thomas Szayna, NATO Enlargement 2000-2015 (Santa Monica, CA: RAND Corporation, 2001), xiii.

17 Tertrais, “The Changing Nature of Military Alliances,” 144.

18 Quoted in Jonathan Haslam, "Russia's Seat at the Table: A Place Denied or a Place Delayed?” International Affairs 74:1 (1998): 122. 
the collective identity, the values and norms of the liberal, Euro-Atlantic community it represents. $^{19}$

Neorealists have difficulties in explaining why NATO has grown. From the perspective of neorealists, "enlargement is puzzling because, as a result of the dissolution of the Warsaw Pact and the Soviet Union, the Russian threat has so strongly diminished and the position of NATO in the international power structure has so vastly improved that enlargement is unnecessary as a balancing strategy." Moreover, it does not implement the neorealist strategy of maximizing power. With enlargement, NATO increases its territory and population, but it does not strengthen its military capabilities. ${ }^{20}$

Nonetheless, in the view of Kenneth Waltz, the enlargement of the Alliance constitutes “an American policy designed to maintain and extend America's grip on European foreign and military policies. Instead of demonstrating the resilience and strength of international institutions, NATO's expansion shows how institutions are shaped to serve what strong countries believe to be their interests." 21

In general, neorealists look at the process of NATO enlargement in a critical manner. They base their analysis mainly on the exploration of the risks and threats connected with this process. Neorealists have argued that "NATO's enlargement may have far-reaching negative consequences for European stability.” ${ }^{22}$ They have opposed the process of enlargement because "it draws new lines of division in Europe, [and] alienates those left out," especially Russia. ${ }^{23}$ Thus, neorealists see NATO enlargement mainly through the lens of relations with the Russian Federation and the risk of damaging Western relations with this country.

Moreover, neorealists also highlight the lack of enthusiasm on the side of NATO members about the trend toward eastward expansion because of the costs connected with the project. ${ }^{24}$ Waltz states further that "the expansion of NATO extends its military interests, enlarges its responsibilities and increases its burdens. Not only do new members require NATO's protection, they also heighten its concern over destabilizing events near their borders." 25 Thus he views the process of NATO enlargement mainly through the lens of potential liabilities and threats. Inviting new nations into the Alliance will bring extended obligations and expenses (because of the limited military capabilities and investments on the part of new members), and will also expose the Alliance to new crises that it will have to cope with (in such hot spots as the Western Balkans).

19 Frank Schimmelfennig, "NATO’s Enlargement to the East: An Analysis of Collective Decision-making,” EAPC-NATO Individual Fellowship Report 1998-2000 (2000), 2; available at www.nato.int/acad/fellow/98-00/schimmelfennig.pdf.

20 Ibid., 5-6.

21 Rauchhaus, "Marching NATO Eastward,” 209.

22 Ibid., 12.

23 Kenneth N. Waltz, “NATO Expansion: A Realist's View,” in Explaining NATO Enlargement, ed. Robert W. Rauchhaus (London: Frank Cass Publishers, 2001), 30.

24 Ibid., 26-27.

25 Ibid., 33. 
Waltz also decries the role played by NATO expansion in the democratization process in Eastern and Central Europe: "One may wonder, however, why this should be an American rather than a European task and why a military rather than a politicaleconomic organization should be seen as the appropriate means for carrying it out. The task of building democracy is not a military one. The military security of new NATO members is not in jeopardy; their political development and economic well-being are."26

Sociological institutionalist theory sees a different rationale for NATO's enlargement after the end of the Cold War. From a sociological point of view, NATO was launched as a military alliance, but over a long period of time it evolved into a transatlantic community based on shared values. ${ }^{27}$ Thus, NATO is not "simply a military alliance but [is] the military organization of an international community of values and norms. ... This community is most fundamentally based on the liberal values and norms shared by its members. Liberal human rights, i.e., individual freedoms, civil liberties, and political rights are at the centre of the community's collective identity." Consequently, one can expect that NATO would invite countries that respect those norms. ${ }^{28}$ As Daniel Fried, U.S. Assistant Secretary of State for European and Eurasian Affairs, asserted: "NATO is not just a military alliance. It is an alliance of values, and NATO's success in the past and promise for the future reflect its fusion of strength and democratic values." 29

Therefore, in the view of sociological institutionalist theory, the adherence to common values is the most important reason why NATO has admitted nations from Central and South East Europe. Reform of a nation's entire state system was the basic condition for an invitation to join NATO. The very existence of the Alliance expresses the importance of common values. These shared values are reflected in the founding act of the Alliance - the North Atlantic Treaty-as well as the Study on NATO Enlargement, which presents guidelines for aspiring countries on how to become a member of the organization. In consequence, the sociological interpretation-unlike that of the neorealists - does not emphasize the Alliance's role in strengthening military security. Consequently, it does not look at the expansion process through the issue of the pooling of military capabilities.

As Rauchhaus argues, "NATO enlargement may help the domestic reform efforts of Eastern European post-communist countries. It ... will create strong incentives for Eastern European countries to improve their civil-military relations, resolve ongoing border disputes, and guarantee the fair treatment of national minorities." ${ }^{30}$ In this inter-

26 Ibid., 34.

27 Rauchhaus, "Marching NATO Eastward," 7.

28 Schimmelfennig, "NATO’s Enlargement to the East,” 8; quoted passage at 9.

29 Daniel Fried, Assistant Secretary of State for European and Eurasian Affairs, "NATO: Enlargement and Effectiveness," testimony before the U.S. Senate Committee on Foreign Relations (11 March 2008), 1; available at www.state.gov/p/eur/rls/rm/102134.htm.

30 Rauchhaus, "Marching NATO Eastward," 4. 
pretation, the prospect of membership has been a great incentive for the countries of the former Communist bloc to transform their systems in the direction of democracy.

\section{Framework of NATO Enlargement}

This section aims to present a framework of NATO enlargement. It examines two main documents that constitute the basis of the accession process of the Alliance: the North Atlantic Treaty and the Study on NATO Enlargement. This section proposes to address the question of admitting new nations from a theoretical point of view. It concentrates on analyzing the conditions that have to be met by an aspiring nation to become a NATO member. Moreover, this section will depict the stages of integration within NATO.

\section{North Atlantic Treaty}

NATO was created by the North Atlantic Treaty signed on 4 April 1949 in Washington, D.C. ${ }^{31}$ This treaty constitutes the most important document in defining the goals and generic functioning mechanisms of the Alliance. Article 10 of the North Atlantic Treaty creates the formal framework for the admission of states to the organization. ${ }^{32}$ This clause explicitly expresses that NATO can invite any "European state in a position to further the principles of ... [the] Treaty and to contribute to the security of the North Atlantic area." This is the only fragment within the founding act of NATO that explicitly addresses the criteria for gaining member status.

One can draw a general conclusion from this fragment of Article 10 that a member state of NATO cannot be a nation from beyond Europe, e.g., from Asia or Africa. Furthermore, a European state aspiring to NATO membership must be able to strengthen the security of the current member states of the Alliance. There are two general problems stemming from this statement. The first deals with how the geographical boundaries of Europe are defined (although one has to bear in mind that an amendment of the records of the Washington Treaty is technically possible). ${ }^{33}$ The second problem with regard to Article 10 refers to an assessment of the contribution of prospective member states to the security of the North Atlantic area. It seems to be purely a question of an interpretation whether a specific country will reinforce the security of the Alliance and to what extent. The evaluation of a state's potential contribution to collective security can vary among member states, which can be a consequence not only of objective arguments, but also of national interests, historical experience, or even of

31 The official text of the North Atlantic Treaty, which will be quoted extensively in this section, is available at www.nato.int/docu/basictxt/treaty.htm.

32 The North Atlantic Treaty does not take into account the possibility of other forms of status than "member." Nevertheless, Greece and Turkey "enjoyed 'observer' status in NATO prior to their full admission in 1952"; Gerald B. Solomon, The NATO Enlargement Debate, 19901997: Blessings of Liberty (Westport, CT: Praeger Publishers, 1998), 20.

33 Article 6 of the North Atlantic Treaty, talking about the area of collective defense ensured by NATO, was modified by the Protocol to the North Atlantic Treaty on the Accession of Greece and Turkey signed on 22 October 1951. 
tactical motivations (e.g., a government's view on enlargement may be an issue in domestic politics). ${ }^{34}$ In this regard, coherence in how a membership candidate is assessed is of the utmost importance, because - as is stipulated in Article 10 of the Washington Treaty-a country is invited to join NATO only "by unanimous agreement."

Within Article 10, one can find a second procedural element of enlargement. Any invited state "may become a Party to the [North Atlantic] Treaty by depositing its instrument of accession with the Government of the United States of America." This means that every member state has to ratify the Accession Protocols according to its own national procedures. Accession Protocols constitute amendments to the North Atlantic Treaty as well as formal invitations of a specific country to accede to the Treaty. ${ }^{35}$

Moreover, "the implicit requirements for membership could be deduced from the short preamble and Articles 1, 2 and 3, which state ... very general goals of justice, democracy, stability, economic collaboration and well-being., 36 One would add two other implicit responsibilities to this list. The first, which can be found in the preamble to the Treaty, refers to the need to respect the "purposes and principles of the Charter of the United Nations." ${ }^{37}$ It obviously imposes on a nation a vast range of general obligations, such as seeking the resolution of disputes by peaceful means. The second relates to the military capacities of a potential member state. In Article 3 one can find the extract declaring that a member state "will maintain and develop [its] individual and collective capacity to resist armed attack." Thus, it imposes further obligation on the ally to create adequate military capabilities in order to be able to effectively contribute to the defense of NATO.

The North Atlantic Treaty also raises the question of a member state's political system. In the preamble one can find reference to "the principle of democracy," which implies that a member of the Alliance should be a democratic state. Nonetheless, NATO's practice during the Cold War era showed that those provisions did not exclude a nation from membership that was not considered to be entirely democratic.

34 Reference to such a concern can be found in Point 30 of the 1995 Study on NATO Enlargement; available at www.nato.int/docu/basictxt/enl-9502.htm.

35 See Gebhardt Von Moltke, "Accession of New Members to the Alliance: What are the Next Steps?” NATO Review 4:45 (1997); available at www.nato.int/docu/review/1997/9704-2.htm. The requirement of ratification may constitute a kind of constraint with regard to a possible invitation to join the Alliance. The Clinton Administration, for example, claimed that the ratification of admission of more than three countries in 1999 (referring to the potential membership of Slovenia, in addition to Hungary, Poland, and the Czech Republic) would be a big challenge for the U.S. Stanley R. Sloan, NATO, the European Union and the Atlantic Community: The Transatlantic Bargain Reconsidered (Lanham, MD: Rowman \& Littlefield Publishers, 2003), 148-49.

36 Anton A. Bebler, The Challenge of NATO Enlargement (Westport, CT: Praeger Publishers, 1999), 49.

37 This is not the only reference to the Charter of the United Nations within the North Atlantic Treaty. Article 5 explicitly invokes Article 51 of the UN Charter, which recognizes the right of individual or collective self-defense. 
This is confirmed in the case of Portugal, one of the twelve original signatories of the Washington Treaty, which possessed "an authoritarian form of government" until the 1970s. ${ }^{38}$ The same situation characterized the admission of Turkey and Greece, which were also not democracies at the time of their accession. ${ }^{39}$

What is also interesting is that "there is no legal basis for the ejection of a state from NATO, within the North Atlantic Treaty or elsewhere. By ejection, I mean revocation of a state's status as a signatory of the North Atlantic Treaty, and thereby of the benefits of the security commitment in Article 5. The only mention of exit from the treaty is in Article 13, which allows for voluntary exit with a year's notice." ${ }^{40}$ However, there was a time when NATO "dealt with members whose governments have not always supported democratic values. When such situations arose-for example, with Greek and Turkish military regimes in the late 1960s and early 1970s—other Allies effectively isolated or excluded them from sensitive discussions. In those instances, suspending either or both would have risked sparking a nationalist backlash against the Allies - or possibly a war between the two long-time adversaries."41

\section{Study on NATO Enlargement}

Another crucial document relating to the question of NATO enlargement was developed in the mid-1990s. During that time one could observe the rising hopes and expectations of the countries of the former Eastern Bloc who were seeking possibilities to deepen their relationships with NATO. One of the developments in this vein was the NATO's publication of a document titled the Study on NATO Enlargement in September 1995. This document "considered the merits of admitting new members and how they should be brought in." ${ }^{42}$ As Bebler notes,

38 Heindel, Kalijarvi, and Wilcox, "The North Atlantic Treaty in the United States Senate," 656.

39 Solomon, The NATO Enlargement Debate, 20.

40 Dan Reiter, “Why NATO Enlargement Does Not Spread Democracy,” International Security 25:4 (2001): 52-53. In this regard, Celeste A. Wallander’s views are particularly interesting. She argues that "NATO members must agree to amend the North Atlantic Treaty to allow for sanction, suspension, or even expulsion of backsliding members"; Celeste A. Wallander, “NATO’s Price,” Foreign Affairs 81:6 (2002): 2. In this article she referred critically to performance of (among others) Hungary and the Czech Republic. A similar view, but not so radical, was expressed by Ronald D. Asmus. He stated that "we should also consider establishing clearer benchmarks for new members to continue to meet after they joined the Alliance. We need to understand that these countries joining NATO does not actually mean they are ready to be full members. We are asking them to meet a set of very minimal standardswith the expectation that the lion's share of reform and work will still take place after they join”; Ronald D. Asmus, "NATO Enlargement and Effectiveness,” testimony before the U.S. Senate Foreign Relations Committee (11 March 2008), 8. Leo Michel, “NATO Decisionmaking: How the 'Consensus Rule’ Works,” National Defense University paper (December 2006), 9; available at www.ndu.edu/inss/research/croatia.pdf. NATO Public Diplomacy Division, Enhancing Security and Extending Stability Through NATO Enlargement (Brussels: NATO, 2004), 4; available at http://www.nato.int/docu/ enlargement/enlargement_eng.pdf. 
The Study ... spelled out, albeit still too generally, the political conditions for being seriously considered as a candidate. These conditions came close to but still clearly fell short of the explicit criteria of admission. They could be characterized as informal considerations or expectations. But since the Study was issued officially by NATO, in spite of its ambivalent title, it was taken (mistakenly) by many in the candidate countries as the definitive list of official criteria of admission. ${ }^{43}$

Therefore, it should be stressed that the Study on NATO Enlargement is not an act that establishes and defines the benchmarks for membership in the Alliance. Rather, the document simply seeks to offer detailed guidance for aspiring countries on how to get closer to NATO and to be finally recognized as candidates for membership.

This view confirms a passage in Chapter 1 of the Study that states "there is no fixed or rigid list of criteria for inviting new member states to join the Alliance. Enlargement will be decided on a case-by-case basis and some nations may attain membership before others." 44 This is one of the key elements of the document. It shows the nature of the process of NATO enlargement, which is flexible, and depends on results of assessments of individual states. It also points out that one cannot predict which state will become a member of NATO, or when it will occur.

However, one can also find in the almost thirty pages of the Study critical information with regard to the potential enlargement of the Alliance. The paper indicates that the prospective process of enlargement will be based on Article $10 .^{45}$ Thus, it confirms that the bedrock of enlargement constitutes the conditions included in this particular segment of the North Atlantic Treaty.

The essence of the Study on NATO Enlargement, however, constitutes the passages that present a number of guidelines that prospective members are to meet prior to accession. These include:

- A functioning democratic political system (including free and fair elections and respect for individual liberty and the rule of law)

- A market economy

- Democratic-style civil-military relations

- Treatment of minority populations in accordance with Organization for Security and Cooperation in Europe (OSCE) guidelines

- Resolution of disputes with neighboring countries and a commitment to solving international disputes peacefully

- A military contribution to the Alliance, including a willingness to take steps to achieve interoperability with other Alliance members.

43 Bebler, The Challenge of NATO Enlargement, 50.

44 Full text of the Study on NATO Enlargement is available at www.nato.int/docu/basictxt/enl9501.htm.

45 The Study on NATO Enlargement quotes Article 10 of the Washington Treaty on pages 2 and 10. 
In addition, NATO requires new members to commit themselves to keeping the door open to further enlargement. ${ }^{46}$

\section{Stages of Integration Within NATO}

The Alliance created several mechanisms to help aspiring member nations meet the above described criteria and the requirements included in the North Atlantic Treaty and the Study on NATO Enlargement. The first mechanism is the Partnership for Peace (PfP), which was launched in 1994. It is the main forum of politico-military cooperation of the Partner nations with NATO. ${ }^{47}$ Currently, there are twenty-four nations participating in the PfP, ${ }^{48}$ and many of them are seeking to join NATO. Thus, should these nations become successful in acceding to NATO membership, it will affect the modes of cooperation that have developed within the framework of the PfP, inter alia, because of the resulting decrease in the number of Partner nations.

Within the PfP framework, one can list a network of mechanisms that aim at facilitating integration within the Alliance. The principal tool is the Membership Action Plan (MAP). Undertaking the MAP process constitutes an important step on the way to Alliance membership, and indicates that a nation is at a higher stage of cooperation aiming at accession. Thus, a country that implements this mechanism is viewed as a candidate state.

However, before an invitation to initiate the MAP is issued, a nation usually develops other mechanisms within the framework of the PfP. Those are the Individual Partnership Action Plan (IPAP) and the Intensified Dialogue (ID). One could say that a classic path to membership in NATO consists of the following steps of integration: joining the PfP; followed by implementation of the IPAP, the ID, and finally the MAP. The concluding and the most important step is obviously the invitation to join the Alliance.

As experience shows, the classic path of integration outlined above today only applies to Bosnia and Herzegovina, Georgia, and Montenegro. After joining the PfP, these nations began to develop first their specific IPAPs, and have now moved on to the ID phase. The small number of states that follow the "classic path" is due to a vari-

46 Thomas Szayna, “NATO Enlargement: Assessing the Candidates for Prague,” Bulletin of the Atlantic Council of the United States 13:2 (2002): 2.

47 For more information on the PfP see NATO, “The Partnership for Peace,” 21 April 2008; available at www.nato.int/ issues/pfp/index.html.

48 There are other two institutions of partnership cooperation within NATO: the Mediterranean Dialogue (MD) and the Istanbul Cooperation Initiative (ICI). MD was established in 1995. The forum gathers seven nations from North Africa and the Middle East: Algeria, Egypt, Israel, Jordan, Mauritania, Morocco and Tunisia. For more information, see NATO, “NATO’s Mediterranean Dialogue” (8 April 2008); available at www.nato.int/med-dial/home.htm. ICI was launched at the NATO Istanbul Summit in June 2004 and is aimed at developing cooperation with nations of the Gulf Cooperation Council. Nowadays, there are four participating countries in ICI: Bahrain, Qatar, Kuwait, and the United Arab Emirates. See NATO, "Istanbul Cooperation Initiative (ICI): Reaching out to the broader Middle East” (31 August 2007); available at www.nato.int/issues/ici/index.html. 
ety of causes. For example, Albania, Croatia, and Macedonia did not develop Individual Partnership Action Plans, because when this mechanism was launched, during the NATO Prague Summit in November 2002, those nations were already developing their Membership Action Plans. Since the latter expresses a higher level of cooperation, there was no reason to revert to the IPAP. Table 1 below presents the level of integration with NATO for eight states. It lists specific NATO mechanisms and the time that their implementation began.

Table 1: The State of Integration of the Group of Eight States with NATO

\begin{tabular}{llcccc}
\hline Country & PfP & IPAP & ID & MAP & Invitation \\
\hline Albania & February 1994 & - & - & 1999 & April 2008 \\
\hline Croatia & May 2000 & - & - & 2002 & April 2008 \\
\hline Macedonia & November 1995 & - & December 2006 & - \\
\hline Georgia & March 1994 & October 2004 & De99 & - \\
\hline Ukraine & February 1994 & - & April 2004 & - & - \\
\hline $\begin{array}{l}\text { Bosnia and } \\
\text { Herzegovina }\end{array}$ & December 2006 & February 2008 & April 2008 & - & - \\
\hline Montenegro & December 2006 & March 2008 & April 2008 & - & - \\
\hline Serbia & December 2006 & - & - & - & - \\
\hline
\end{tabular}

As was discussed above, the MAP constitutes a crucial step on the path to NATO membership. The MAP was launched during the NATO Washington Summit in April 1999. It is "a program of advice, assistance, and practical support tailored to the individual needs of countries wishing to join the Alliance. The MAP is not simply a checklist for aspiring countries to fulfill, but instead is a process which helps these nations focus their preparations on meeting the goals and priorities set out within it and provides a range of activities designed to strengthen each country’s candidacy."

The establishment of the MAP mechanism was based on the experience of the first wave of NATO enlargement after the Cold War. As Donnelly and Simon note, "The MAP is an excellent way to measure the capacities of each country and to structure the enlargement process. Experience with the first three new NATO countries (the Czech

49 Sverre Myrli (rapporteur), “The Three Adriatic Aspirants: Capabilities and Preparations,” Committee Report to the NATO Parliamentary Assembly (6 October 2007), 3. 
Republic, Hungary and Poland) since admission in 1999 has demonstrated that there has been a large divergence between what a country says it can do and what the country can actually deliver."50

What is most important about the MAP process is that it supports meeting the guidelines introduced by the Study on NATO Enlargement and also allows a thorough assessment of the performance of every aspiring state. As Jiri Šedivý notes, "The general areas covered by MAP's activities are identical to those outlined in the Study on NATO Enlargement (political and military, defense/military, resources, security and legal) which guided the first enlargement process. Yet the current aspirants are, through a sophisticated structure of MAP instruments, subjected to more profound scrutiny and in-depth evaluation. The feedback from NATO on their progress is more critical and discriminatory than was the case for their predecessors." 51

Thus, the MAP can be perceived as a reflection, as Ronald Asmus put it, of "tough love" on the part of the Allies toward aspiring nations. ${ }^{52}$ By establishing the MAP, NATO wanted to show that there are criteria for membership, and to outline the mechanism for verifying whether or not these criteria had been met.

However, it should be emphasized - especially in the context of current discussions on Georgia and Ukraine-that implementation of the MAP "does not prejudge any decision by the Alliance on future membership." ${ }^{53}$ According to the framework of NATO enlargement, first, a country should meet all benchmarks defined by the Alliance; second, that country's accession must be agreed to by all members of the Alliance. This also means that there is no defined timeframe for the implementation of the MAP in order to be invited to join NATO. Experience shows that specific countries need different amounts of time-e.g., Albania spent nine years developing the MAP before being invited to sign membership accords in July 2008, whereas Croatia spent only six years in the MAP phase.

The Intensified Dialogue phase is an earlier step in the process of integration within NATO. It is viewed as the stage of cooperation preceding implementation of the MAP, but following on from participation in the Partnership for Peace. The ID gives a prospective member state "access to a more intense political exchange with NATO Allies on its membership aspirations and relevant reforms, without prejudice to any eventual

50 Chris Donnelly and Jeffrey Simon, "Roadmaps to NATO Accession: Preparing for Membership,” East European Studies Meeting Report no. 242 (January 2002); available at www.wilsoncenter.org/index.cfm?event_id=5976\&fuseaction=events.event_summary. Compare with Paul Belkin, Carl Ek, Julie Kim, Jim Nichol, and Steven Woehrel, Enlargement Issues at NATO's Bucharest Summit, CRS Report for Congress (Washington, D.C.: Congressional Research Service, 12 March 2008), 3.

51 Jiri Šedivý, “The Puzzle of NATO Enlargement,” Contemporary Security Policy 22:2 (2001): 3. Šedivý, in his statement, referred to the countries that were admitted to NATO during the first round of enlargement after the Cold War (the Czech Republic, Hungary and Poland). They were not implementing the MAP.

52 Ronald D. Asmus, "NATO Enlargement and Effectiveness," testimony before the U.S. Senate Foreign Relations Committee (11 March 2008), 4.

53 NATO, “Membership Action Plan (MAP),” available at www.nato.int/issues/map/index.html. 
Alliance decision on further membership." ${ }^{54}$ Nowadays, there are four nations in the Intensified Dialogue phase: Bosnia-Herzegovina, Georgia, Montenegro, and Ukraine.

The Individual Partnership Action Plan is an even earlier phase in the integration process, coming before the initiation of the Intensified Dialogue. It serves as yet another mechanism of developing cooperation between NATO and a partner nation. It is a tool designed to deepen politico-military relations with the Alliance. Within this mechanism countries implement activities in the following areas: political and security issues; defense, security and military issues; public information; science and environment; civil emergency planning; and administrative, protective security, and resource issues. The IPAP, launched at the NATO Prague Summit in 2002, was created mainly for the Partner nations from the South Caucasus (e.g. Georgia) and Central Asia (e.g. Kazakhstan), but today is also implemented by countries aiming at joining the Alliance, such as Bosnia-Herzegovina and Montenegro. ${ }^{55}$

To summarize, one can draw a general conclusion that the process of NATO enlargement is based on a formal framework. The basis of this system constitutes the records of the North Atlantic Treaty, especially Article 10, and the Study on NATO Enlargement. However, expansion of the Alliance is a flexible process based on political evaluations made by NATO members. Those acts define requirements that must be met in order for a state to be recognized as a qualified country and finally to be invited to join NATO. However, what should be underlined is that the fulfillment of all these criteria does not guarantee accession to the Alliance. On the other hand, paradoxically, the lack of implementation of all required reforms does not exclude an invitation to join NATO either.

\section{History of NATO Enlargement}

This section aims at outlining the previous rounds of NATO enlargement. It looks at the three distinct waves of NATO expansion that took place: one during the Cold War period, and two after the collapse of the Berlin Wall. The Cold War rounds of enlargement were as follows: Greece and Turkey in 1952; the Federal Republic of Germany in 1955; and Spain in 1982. Since the end of the Cold War, there have been two additional waves of expansion, which embraced countries from Eastern and Central Europe that were previously members of the Warsaw Pact. Thus the Czech Republic, Hungary, and Poland joined NATO in 1999, whereas Bulgaria, Estonia, Latvia, Lithuania, Romania, Slovakia, and Slovenia joined in 2004. A third post-Cold War enlargement round has been launched with the invitation of Albania and Croatia during the 2008 Bucharest Summit.

Turkey and Greece were admitted to NATO in 1952, which was justified mainly on strategic and security grounds. It was connected with the "difficulties faced by Greece after World War II in quelling a communist rebellion and demands by the Soviet Un-

54 NATO, “NATO Offers Intensified Dialogue to Georgia," NATO Update (21 September 2006); available at www.nato.int/docu/update/2006/09-september/e0921c.htm.

55 NATO, “Individual Partnership Action Plans,” 15 April 2008; available at www.nato.int/ issues/ipap/index.html. 
ion for military bases in the Turkish Straits."56 This situation arose from the so-called Truman Doctrine, which was first articulated in 1947. "The doctrine enunciated American intentions to guarantee the security of Turkey and Greece and resulted in large scale U.S. military and economic aid." ${ }^{, 5}$ The accession of those two countries enabled the Alliance to "shore up its southern flank to forestall Communist military action in Europe at the height of the Korean War." ${ }^{\text {" }}$ Turkey's location in particular has been of great importance from NATO's point of view. It "serves as the organization's vital eastern anchor, controlling the straits leading from the Black Sea to the Mediterranean and sharing a border with Syria, Iraq, and Iran." ${ }^{59}$ Turkey's military potential was also a significant consideration; indeed, "among NATO countries, its military establishment has ranked second in size to that of the United States.",60

The Federal Republic of Germany became a member of NATO in 1955. This fact meant that the primary adversary of the Second World War was invited to join the Alliance of the Western world, "despite initial protests by both France and the Soviet Union.” ${ }^{61}$ For the Federal Republic of Germany, this was an important step in its "postwar rehabilitation and paved the way ... to play a substantial role in the defense of Western Europe during the Cold War." 62 In addition, accession to NATO returned to Germany much of its sovereignty, which had been in abeyance during the post-World War Two occupation period. One should bear in mind that, after the unification of Germany in October 1990, the area of NATO was broadened to include the territory of the former German Democratic Republic, though understandably it did not mean the increase of the number of member states. ${ }^{63}$

${ }^{56}$ U.S. Department of State, Bureau of European and Eurasian Affairs, Background Note: Turkey (Washington, D.C.: U.S. Department of State, 2007); available at www.state.gov/r/pa/ ei/bgn/3432.htm.

57 Ibid.

58 United States General Accounting Office, NATO Enlargement, Report to Congressional Committees (Washington, D.C.: GAO, November 2002); available at www.gao.gov/ new.items/d03255.pdf.

59 U.S. Department of State, Background Note: Turkey.

${ }^{60}$ Isaiah Frank, “A Place for Turkey,” Washington Post (28 September 1999): A25.

61 Charly Salonius-Pasternak, From Protecting Some to Securing Many: NATO's Journey from a Military Alliance to a Security Manager, FIIA Report 17 (Helsinki: Finnish Institute of International Affairs, 2007), 21. France did not want to agree to a rearmament of the Federal Republic of Germany in the recent aftermath of the Second World War; see Helga Haftendorn, “Germany’s Accession to NATO: 50 Years On,” NATO Review (Summer 2005): 2. Haftendorn, Ibid., 1.

63 August Pradetto and Fouzieh Melani Alamir, eds., Die Debatte über die Kosten der NATOOsterweiterung (Baden-Baden: Nomos, 1998), 261. 
Spain became a member of NATO in 1982, following three decades of special defense arrangements with the U.S. on hosting sea and air bases. ${ }^{64}$ Spain's strategic location at the southern end of Europe at the Mediterranean Sea, Atlantic Ocean, and Straits of Gibraltar was long appreciated within the Alliance. ${ }^{65}$ However, Spain's application to join the Alliance generated "heated domestic discussion when the conservative government applied for membership in contradiction to a previous consensus to not seek membership." ${ }^{\text {"6 }}$ Spain was very close to withdrawing from the Alliance when, shortly after the application was made, "the Socialist Party, officially hostile to the Alliance, took power and Prime Minister Felipe Gonzalez promised a national referendum on NATO membership." ${ }^{, 67}$ In the referendum held in 1986, Spaniards voted to stay in NATO. ${ }^{68}$ What is interesting, however, is that Spain joined the integrated military structure of the Alliance only in $1998 .{ }^{69}$

There were two waves of enlargement that embraced former members of the Warsaw Pact in Eastern and Central Europe. First, the so-called Visegrad Three-the

${ }^{64}$ The American presence had been causing tensions in Spain. "The sensitivity over NATO and the American bases comes largely from a Spanish perception that the 1953 treaty establishing the bases broke [Francisco] Franco's international isolation and saved his regime from falling. In February [1985], the expulsion of two American diplomats here accused of spying and the disclosure of contingency plans to store nuclear weapons in Spain added salt to the historical wounds.” Edward Schumacher, "Issues in Madrid Awaiting Reagan,” New York Times (5 May 1985): A19.

During the Cold War era, Spain was part of NATO's “defense in depth” strategy. In the event of war in Central Europe, Spain was seen as a key rear base for shuttling troops and supplies to the front and as a vital point to help control the Straits of Gibraltar, the Western Mediterranean, and the Atlantic around the Canary Islands, all important passages for convoys. Edward Schumacher, "If Spain Leaves NATO Both Could Be the Poorer," New York Times (9 March 1986): A2. Edward Schumacher, "The Cloudy Outlook for Gibraltar's Commanding View,” New York Times (10 February 1985): A5.

68 "In return for approval by Spaniards of continued NATO membership, Gonzalez promised his leftist electorate that Spain would not host nuclear weapons or fully integrate into NATO militarily. The third condition was that there would be a significant reduction in American military presence.” Jim Hoagland, "Spain’s Move Stirs NATO Concern. Allies Fear Spillover Problems If U.S. Warplanes Are Ousted,” Washington Post (29 December 1987): A9. NATO, Summit Guide (March 2008); available at www.nato.int/docu/comm/2008/0804bucharest/guide.html. 
Czech Republic, Hungary, and Poland-joined NATO in $1999 .^{70}$ The second wave saw seven other countries-Bulgaria, Estonia, Latvia, Lithuania, Romania, Slovakia, and Slovenia-follow suit in 2004.

The rounds of expansion that took place in 1999 and 2004 were distinct from those that occurred during the Cold War. The "enlargements were qualitatively and quantitatively different from the previous enlargements. Quantitatively, in the space of five years, the number of NATO members rose from 16 to 26. The enlargements significantly extended the 'Alliance border areas' adjoining Russia, and increased the size of the area under the collective security umbrella in Europe by nearly 30 percent."

What was the rationale for the two post-Cold War waves of enlargement? As Ronald D. Asmus argues, there were three main goals of the expansion of NATO to ten post-communist countries: to build a post-Cold War Europe "whole, free, and at peace"; to renew the transatlantic alliance; and to reposition the United States and Europe to address global challenges. ${ }^{72}$ This view confirms the words of Bill Clinton, who in a June 2001 speech at Warsaw University said that the rationale for enlargement was to create a "Europe whole and free."73

With regard to the expansion of NATO which took place in 2004, one can say that the events of 11 September 2001 in the U.S. played an important role in the inclusion of the nations from not only Eastern and Central Europe, but also the Western Balkans. The strategic location of Bulgaria and Romania has been of great importance for the U.S. in the war against terrorism. In this respect, the Bush Administration has believed

70 The first wave of enlargement of NATO was limited only to three countries from East-central Europe. However "France and Italy in particular had pressed strongly to include Romania and Slovenia in the group of membership candidates - in opposition to many other Allies, particularly the U.S." (Karl-Heinz Kamp, "NATO Entrapped: Debating the Next Enlargement Round," Survival 40:3 (1998): 170.) "Paris raised the stakes by linking its possible return to the integrated military structure of NATO to the extension of membership to Romania and Slovenia plus the appointment of a European, rather than an American, commander of Allied Forces South (AFSOUTH). Other south European states supported Slovenia's and Romania's case along with the French, but opposed Paris over the AFSOUTH command." (Stuart Croft, "Guaranteeing Europe's Security? Enlarging NATO Again,” International Affairs 78:1 (2002): 104.) Salonius-Pasternak, From Protecting Some to Securing Many, 22.

Ronald D. Asmus, "Europe's Eastern Promise: Rethinking NATO and EU Enlargement," Foreign Affairs 87:1 (2008): 95.

73 During that speech President Clinton said: "I believe in NATO membership for all of Europe's democracies that seek it and are ready to share the responsibilities that NATO brings. The question of 'when' may still be up for debate within NATO; the question of 'whether' should not be. As we plan to enlarge NATO, no nation should be used as a pawn in the agendas of others. We will not trade away the fate of free European peoples. No more Munichs. No more Yaltas. Let us tell all those who have struggled to build democracy and free markets what we have told the Poles: from now on, what you build, you keep. No one can take away your freedom or your country." The White House, "Remarks by the President in an address to faculty and students of Warsaw University,” Warsaw, Poland, 15 June 2001; available at www.whitehouse.gov/news/releases/2001/06/20010615-1.html. 
that "an enlarged Alliance that conducts joint defense and operational planning, promotes interoperability, and encourages realistic training exercises will be a more effective partner in answering global security challenges."74 Without question, "Bulgaria and Romania became beneficiaries of the September 2001 crisis. Admission of these two could give NATO a coherent and geostrategically significant 'southern dimension,' connecting Hungary through the Balkans to Greece and Turkey.”,75

\section{The Debate on NATO Enlargement}

The aim of this section is to analyze the debate on the future of NATO enlargement, in order to gain a better understanding of the character of discussions on the expansion of the Alliance. Here I will examine a few chosen important questions that influence the decisions made with regard to the expansion of the Alliance. The section begins with a presentation of the main decisions made during two last NATO summits in Riga (November 2006) and Bucharest (April 2008). It provides background for the exploration of other issues later in this essay, such as: the strategic dimension of expansion; responsibilities stemming from Article 5 of the North Atlantic Treaty; the military contribution expected from new member states; support for NATO enlargement; the Russian factor; and the decision-making process around enlargement.

\section{Enlargement on the Agenda of NATO}

There are currently nine countries that are viewed as prospective NATO members. They are located in the Western Balkans, Eastern Europe, and the South Caucasus. Albania and Croatia were already invited during the Bucharest Summit to begin accession talks, and signed membership accords in July 2008. The third country from the Western Balkans, Macedonia, is a formal aspirant for NATO membership and is currently implementing its Membership Action Plan. One can also list several other countries that are part of the enlargement debate: Georgia and Ukraine, which are developing the Intensified Dialogue with NATO; and Bosnia and Herzegovina, Serbia, and Montenegro which joined the PfP program in December 2006. One can also look at Kosovo-a newly independent state in the Western Balkans-as a potential future member of NATO.

Enlargement is an important matter on the NATO agenda. However, one can certainly say that primary attention is given nowadays to other issues, such as the operations in Afghanistan, and the military transformation of the Alliance itself. This fragmented attention results in a less vibrant and vivid debate in Europe and North America as it did in the case of the first (or even second) round of NATO enlargement after the end of the Cold War. The process of Euro-Atlantic integration concentrates mainly

${ }^{74}$ Rebecca R. Moore, NATO's New Mission: Projecting Stability in a Post-Cold War World (Westport, CT: Praeger Security International, 2007), 79.

75 Michael Clarke and Paul Cornish "The European Defence Project and the Prague Summit," International Affairs 78:4 (2002): 779-80. 
on the question of meeting membership criteria. Nonetheless, NATO today faces a few complicated cases of integration, particularly Macedonia, Georgia, and Ukraine.

The issue of enlargement was not the central topic of the NATO Summit held in Riga in November 2006. During that meeting, the Allies focused on the question of military missions, mainly in Afghanistan (ISAF) and Kosovo (KFOR), as well as the transformation of NATO. ${ }^{76}$ The Alliance did not make any important decision in Latvia with regard to aspiring member countries. Nevertheless, representatives of twentysix member states habitually reaffirmed that "NATO remains open to new European members under Article 10 of the North Atlantic Treaty.” There was another crucial message that came from the heads of state gathered in Riga: "At our next summit in 2008, the Alliance intends to extend further invitations to those countries that meet NATO's performance-based standards and are able to contribute to Euro-Atlantic security and stability.",77 Obviously, the Allies had in mind three Balkan states-Albania, Croatia, and Macedonia - which were closest to NATO membership.

A few weeks before the April 2008 NATO Summit held in Bucharest, SecretaryGeneral Jaap de Hoop Scheffer announced that the question of enlargement would be the second-most important issue on the agenda of the Bucharest Summit, after the operational engagement of the Alliance. However, he also underscored that the decision with regard to three MAP countries had not yet been made, and it would depend upon the fulfillment of membership criteria. Thus, he emphasized that the possible invitations to negotiations with the Alliance would depend on the performance of the candidate countries. $^{78}$

Nonetheless, it is unquestionable that, during the last summit in Bucharest, one of the key issues on the agenda was NATO's "open door policy."79 What is noteworthy is that the Bucharest Summit Declaration issued after the meeting began with the statement "[we] met today to enlarge our Alliance," highlighting the significance of the decisions made on NATO expansion. ${ }^{80}$

76 Jaap de Hoop Scheffer, “Opening Statement by NATO Secretary General at the Meeting of the North Atlantic Council at the Level of Heads of States and Government," 29 November 2006; available at www.nato.int/docu/speech/2006/s061129b.htm.

77 NATO, "Riga Summit Declaration," 29 November 2006; available at www.nato.int/docu/pr/ 2006/p06-150e.htm.

78 Jaap de Hoop Scheffer, “Looking ahead to NATO’s Bucharest Summit,” Speech by NATO Secretary-General Jaap de Hoop Scheffer at Bucharest University, Romania (11 January 2008); available at www.nato.int/docu/speech/2008/s080111a.html.

79 Other important topics touched upon during the Bucharest Summit were military operations (especially ISAF in Afghanistan and KFOR in Kosovo), military transformation of the Alliance, partnership policy, missile defense, energy security, and the relationship between NATO and the EU. See NATO, "Bucharest Summit Takes NATO Agenda Forward,” (3 April 2008); available at www.nato.int/docu/update/2008/04-april/e0403f.html.

80 NATO, "Bucharest Summit Declaration," issued by the Heads of State and Government participating in the meeting of the North Atlantic Council in Bucharest (3 April 2008); available at www.nato.int/docu/pr/2008/p08-049e.html. 
The discussions before and during the meeting were very intense. Since there was a consensus to invite Albania and Croatia to initiate accession talks, the debate concentrated mainly around two questions: the bilateral dispute between Greece and Macedonia, and the invitation of Ukraine and Georgia to initiate the MAP process. Ultimately, NATO made two crucial decisions with regard to enlargement policy. The member states invited Albania and Croatia to begin accession talks, and granted $\mathrm{BiH}$ and Montenegro Intensified Dialogue status. NATO underscored that Albania and Croatia will soon become members thanks to "years of hard work and a demonstrated commitment to ... common security and NATO's shared values.” NATO stressed that "the accession of these new members will strengthen security for all in the Euro-Atlantic area, and bring us closer to our goal of a Europe that is whole, free, and at peace." ${ }^{\prime \prime}$

With regard to the procedural aspects of joining NATO, the invited countries began accession talks after the summit meeting. After this, the Protocols of Accession will be ratified by the NATO member states. Finally, one can expect that Albania and Croatia will become full-fledged members in the following year, in summer or fall $2009 .^{82}$

During the Bucharest Summit, Macedonia's performance in the larger processes of Euro-Atlantic integration was welcomed and praised, but the country was not invited to join the Alliance because of their bilateral dispute with Greece. The latter state used its veto power in the organization to block the invitation. However, Macedonia was ensured by the Alliance that an invitation "will be extended as soon as a mutually acceptable solution to the name issue has been reached." 83

The invitation of Bosnia and Herzegovina and Montenegro to the ID was not a surprise. Those countries are interested in deepening their relations with the Alliance, and hope to eventually accede to membership. The third country from the Western Balkans, Serbia, was also offered this mechanism, but did not express any interest in it. Nevertheless, NATO member states wanted to send a signal that they would welcome strengthening relations with Serbia. This is why in the Bucharest Summit Declaration one can find a provision that NATO is ready to deepen its cooperation with Serbia and "will consider an Intensified Dialogue following a request by Serbia." 84

81 Ibid.

82 In the past, the Czech Republic, Hungary, and Poland were invited to join the Alliance during the Madrid Summit in July 1997, and became members in March 1999. Bulgaria, Estonia, Latvia, Lithuania, Romania, Slovakia, and Slovenia were invited during the Prague Summit in November 2002, and gained member status in March 2004. Thus, Albania and Croatia should become members of the Alliance in 2009.

83 NATO, "Bucharest Summit Declaration.” According to Henri Bohnet, director of the Skopje office of the Germany-based political think tank the Konrad Adenauer Stiftung, "the main reason why neither party came to an agreement was due to the fact that negotiations started far too late-only two or three months in advance-when really it all should have been concluded a year ago." Seeurope, "Region: Mixed Fortunes for Southeast Europe at Bucharest's NATO Summit," (14 April 2008); available at www.seeurope.net/?q= node/15321 (accessed 10 June 2008; URL is now disabled).

84 NATO, "Bucharest Summit Declaration." 
MAP status was not granted to Georgia and Ukraine during the Bucharest summit. However, the Allies stated that "MAP is the next step for Ukraine and Georgia on their direct way to membership." Furthermore, in the Bucharest Summit Declaration one can find the following direct statement of intention: "these countries ... will become members of NATO." This stipulation allows one to infer that the decision about granting MAP status (and an eventual invitation to the Alliance) has been postponed, but that Georgia and Ukraine will certainly become members. ${ }^{85}$

All in all, this statement constitutes quite an unusual commitment on the part of the Alliance. The organization has always avoided declarations entailing any future decisions directed at any specific state. It is clear that Ukrainian President Viktor Yushchenko welcomed this statement. During the meeting of the NATO-Ukraine Commission (NUC) held in Bucharest (4 April 2008), he stated that the decision "gave a clear signal on future relations of Ukraine with NATO. ${ }^{\text {"86 }}$ He added, "Here we got a 100 percent guarantee, at least formally, for membership," and his overall assessment of the summit's decisions was straightforward: "This is our victory." ${ }^{87}$ Georgian Foreign Minister David Bakradze had a similar assessment of the summit, describing it as a "historic breakthrough" for the nation. ${ }^{88}$ Overall, the Allies introduced some new statements in the Bucharest Summit Declaration. Further assessment of Georgia and Ukraine's MAP applications will be carried out during the Foreign Ministers meeting in December 2008.

During the Bucharest Summit, the Allies devoted much time to discussing the question of Kosovo. However, the debate concentrated on NATO's operational commitments to help to stabilize the security situation in that country. The Alliance again reiterated that KFOR will remain in Kosovo to "ensure a safe and secure environment." ${ }^{89}$ Member states did not take up the question of the broader Euro-Atlantic inte-

${ }^{85}$ Ibid. During the discussions in Bucharest, the Allies "argued over the exact wording of the final communiqué, in particular how to frame the rejection of Ukraine and Georgia. In the end, they only offered rhetorical support for these countries' aspirations, saying only that they would be members of NATO one day." Steven Lee Myers and Graham Bowley, "Bush Wins NATO Backing on Shield, but not on Ukraine and Georgia," International Herald Tribune (3 April 2008); available at www.iht.com/articles/2008/04/03/europe/3shield.php. NATO, “NATO-Ukraine Commission Discusses a New Phase of Relations” (4 April 2008); available at www.nato.int/docu/update/2008/04-april/e0404a.html.

87 RFERL, "NATO: No MAP for Georgia or Ukraine, but Alliance Vows Membership," (3 April 2008); available at www.rferl.org/content/Article/1079726.html; David Brunnstrom and Susan Cornwell, "NATO Agrees Former Soviet Republics Will One Day Enter," International Herald Tribune (3 April 2008); available at www.iht.com/articles/reuters/2008/ 04/03/europe/OUKWD-UK-NATO.php. 
gration of Kosovo. It is a clear sign that NATO sees embarking on the debate of possible future membership for the country as premature. ${ }^{90}$

\section{Strategic Dimension}

The continuing enlargement of NATO generally aims at strengthening the level of security and stabilization in the entire Euro-Atlantic area as well as consolidating the democratization process in the post-communist countries. This applies to the Western Balkans as well. NATO recognizes the importance of that region and has stressed that "Euro-Atlantic integration, based on solidarity and democratic values, remains necessary for long-term stability." ${ }^{11}$ The strategy of NATO towards the Western Balkans "aims to consolidate stability in Southeast Europe and facilitate the integration of Albania, Bosnia and Herzegovina, Croatia, Montenegro, Serbia, and ... Macedonia into Euro-Atlantic structures." 92 NATO has been engaged in the process of stabilization of the Western Balkans for a long time by conducting peacekeeping operations (e.g., IFOR/SFOR, KFOR) and developing politico-military cooperation, by assisting with the process of security and defense sector reform. ${ }^{93}$

The invitation of Albania and Croatia-as well as the plausibility of future membership for Macedonia, BiH, Montenegro, Serbia, and Kosovo-will therefore be one of the crucial elements of the stabilization process in the Western Balkans. NATO Secretary-General Jaap de Hoop Scheffer stated just one day before the Bucharest Summit that he hopes that enlargement will "give the Balkans region the boost of stability and confidence that it needs." ${ }^{94}$ Additionally, it will be a continuation of the process of NATO expansion to the region after having admitted Bulgaria, Romania, Hungary, and Slovenia to the organization. Furthermore, the location of those states close to the Mediterranean and the Middle East is not insignificant for the Alliance. NATO has been broadly involved in those geographic areas by conducting operations (Active Endeavour in the Mediterranean and the NATO Training Mission in Iraq) and developing ties with partner nations from MD and ICI.

90 James Appathurai, NATO Spokesman, made a very interesting statement on Kosovo: "With regard to Kosovo, ... I think again we shouldn't be getting ahead of ourselves. There are a number of very important issues that we're dealing with right now as an international community with regard to Kosovo and NATO playing a very important role backstopping the security environment. So, I have not heard any discussion or any decision within NATO of looking forward beyond addressing now what are the immediate challenges related to Kosovo.” Press briefing by NATO Spokesman James Appathurai, 2 April 2008; available at www.nato.int/docu/speech/2008/s080402e.html.

91 NATO, “Riga Summit Declaration,” 2006.

92 NATO, “NATO in the Balkans,” 24 January 2008; available at www.nato.int/issues/balkans/ index.html.

93 NATO, "Bringing Peace and Stability to the Balkans," February 2005; available at www.nato.int/docu/briefing/balkans/balkans-e.pdf.

94 NATO, Keynote speech by NATO Secretary General Jaap de Hoop Scheffer and Panel intervention at the Bucharest Conference (GMF), 2 April 2008; available at www.nato.int/ docu/speech/2008/s080402b.html. 
The geographical reach of the Alliance in the Balkans will be expanded. Albania and Croatia have been already invited to NATO, and it seems that Macedonia will join this group soon. If this scenario is implemented, Greece will gain two new neighbors that are the part of the Alliance (Albania and Macedonia). In the northern part of the Western Balkans, Croatia - which borders two member states, Hungary and Slovenia-will expand NATO's reach with an extensive coastline along the Adriatic Sea.

There is no doubt that the location of Ukraine is of particular strategic importance. The country is situated on the Black Sea and borders four NATO member states (Romania, Hungary, Slovakia and Poland) as well as the Russian Federation. Ukraine, which is the second largest country in Europe (603 thousand $\mathrm{km}^{2}$ ), creates a kind of buffer zone between the members of the Alliance and Russia. NATO recognized the strategic importance and military potential of Ukraine by signing the "Charter on a Distinctive Partnership" in July 1997. This is the only country, beside the Russian Federation, which has developed special relations with NATO. Ukraine is also very important from the perspective of some individual NATO member countries. Ukraine's accession to the organization would be especially important for Allies along the Eastern flank of NATO that share a border with Ukraine, such as Poland and Slovakia. The strategic importance of Ukraine is also recognized by the Russian Federation. It is one of the reasons why this state opposes eastward NATO enlargement.

Georgia's location is seen as strategic, but at the same time can be perceived as problematic. $^{95}$ The state shares a border with one NATO member state (Turkey) and also adjoins the Russian Federation. The Alliance views Georgia "as a key buffer state in the Caucasus, one whose mere existence holds Russia in check." However, this location, bordering the Russian Federation and on the Eastern shore of the Black Sea, means that this state is also seen as "too dysfunctional and isolated for NATO to ever be able to adequately defend it." 96 Furthermore, the South Caucasus region is perceived as unstable, because of (among other reasons) the conflict over Nagorno-Karabakh and the general political situation in the countries of this area.

Georgia's situation is even more complex, however. According to the provisions of Article 10 of the Washington Treaty, enlargement to new countries should strengthen the security of NATO member states. From a strategic point of view, the current situation in Georgia indicates that NATO's security will not be strengthened by Georgia's accession. The main reason is the lack of territorial integrity of Georgia because of the existence of two breakaway regions of Abkhazia and South Ossetia - a situation that erupted into armed conflict in August 2008, with Russian troops occupying both breakaway provinces (where they had previously stationed "peacekeeper" troops) and invading border sections of Georgia itself. In consequence, this state of affairs complicates Georgia's security situation, and exposes other member states to risk as well. This is one of the main reasons why a few countries of the Alliance are reluctant to in-

95 Editorial Board comment: This paper was written before the crisis of August 2008, but the argument remains of interest.

96 Stratfor, "Georgia: A NATO Move to Calm Tensions," 4 October 2007; available at www.stratfor.com/analysis/georgia_nato_move_calm_tensions (membership required). 
vite Georgia even to begin the MAP phase, which constitutes the next step on the path to membership after developing the ID. Those states are also afraid of the possible political consequences, as this move would strongly strain NATO's relations with the Russian Federation.

When examining the strategic dimensions of NATO expansion, it can also be viewed as a parallel and reinforcing process of stabilization along with the expansion of the EU. Both organizations are based on common values: respect for democracy, fundamental freedoms, and a market economy. Both institutions are in the process of enlargement. However, while "the EU is said to be suffering from enlargement fatigue, NATO does not send a signal that it is also losing heart in the process of Euro-Atlantic integration." 97

There is no formal link between the membership processes for NATO and the EU; each institution has established its own unique arrangements for how to become a member. ${ }^{98}$ However, there is no doubt that both organizations have influence on each other. Twenty-one nations are members of both NATO and the EU. It is also important that those institutions develop strategic partnership and politico-military cooperation, in both the ideological and the operational realms. Furthermore, "the EU and NATO have increasingly come to cover the same tasks in the same geographical area. For the newcomers, in particular, the overlapping membership is expected to facilitate both cooperation and convergence." 99 Therefore, overlapping membership can be seen as highly beneficial.

Ten countries in Eastern and Central Europe that had been admitted to NATO (1999 and 2004) later became members of the EU (in 2004 and 2007). One can draw the conclusion that accession to NATO helps in becoming an EU member, since it traditionally precedes EU membership. It is true, however, that one cannot treat becoming a NATO member as a condition for being admitted to the EU. Those two processes of integration are interlinked (e.g., meeting democracy benchmarks), but very distinct and without any direct correlations and dependencies.

Nowadays, three Western Balkans countries also intend to join the EU. Croatia and Macedonia have the status of official candidates for membership. Croatia started its negotiations with the EU in 2005, whereas Macedonia has not yet begun formal talks. Albania signed Stabilization and Association Agreement (SAA) with the EU in 2003, as did Serbia in 2008. Bosnia and Herzegovina, Montenegro, and Kosovo are seen as

97 Jamie Shea, "Reflections on NATO’s Political and Military Transformation Since 9/11," Turkish Policy Quarterly 5:3 (2006).

98 A very interesting but at the same time humorous and sarcastic comparison of the processes of integration within the EU and NATO and requirements connected with it was made by former German defense minister Volker Rühe, who stated, "You can join the Atlantic Alliance with old tanks, but joining the EU with old farm tractors causes problems.” Quoted in Zoltan Barany, "NATO Expansion, Round Two: Making Matters Worse,” Security Studies 11:3 (2002): 69.

99 Antonio Missiroli, “Central Europe Between the EU and NATO,” Survival 46:4 (2004): 131-32. 
potential future members of the EU. With regard to Ukraine and Georgia, those countries have signed Partnership and Cooperation Agreements (PCA) with the EU. ${ }^{100}$ It is very important that membership in NATO, just as the process of integration itself, is widely perceived to have a positive impact on the process of stabilization of these nations' internal situation.

\section{Responsibilities under Article 5 of the North Atlantic Treaty}

One of the facets of the discussion on enlargement relates to responsibilities stemming from Article 5 of the North Atlantic Treaty. ${ }^{101}$ There is no doubt that the character of security threats and challenges has changed, and nowadays the possibility of an armed conflict is decreasing. ${ }^{102}$ Subsequently, the Alliance has been transforming "from a defense body to an institution dealing primarily with out-of-area problems." ${ }^{103}$ Nonetheless, collective defense remains the core function of the Alliance. Therefore, the member states as well as aspiring countries must meet the challenges of contributing to collective defense.

Prospective NATO members attach great importance to the security guarantees resulting from Article 5. This is still one of key motivations why they seek to join the Alliance. For the aspiring countries, NATO membership is mainly seen as a guarantee to ensure their territorial integrity. This is particularly important due to the complicated history of many of these countries, their newly established statehood, their relatively limited military capabilities, and the fact that many of them are located in regions where the security situation still has not stabilized. Therefore, for prospective members the security guarantees stemming from Article 5 of the Washington Treaty are extremely important. Membership in NATO is seen as significantly increasing the level of security of those countries.

Moreover, if NATO enlarges, there will be other implications for the Allies. The size of the area that will have to be secured will change significantly, especially after the invitation of Ukraine, which is the second-largest country in Europe. This will have operational implications for the Allies, who would have to explore how to effectively ensure security and provide security guarantees across suddenly much larger distances. It will certainly influence the process of defense planning, and will alter the resources required to carry out an action under Article 5. Furthermore, a possible intervention to

100 To find more information on EU enlargement, see the European Commission's website, at http://ec.europa.eu/enlargement/index_en.htm.

${ }^{101}$ In the history of NATO, Article 5 has been invoked only once, immediately after the terrorist attacks on the U.S. in September 2001.

${ }^{102}$ According to Michael Clarke and Paul Cornish, "collective self-defense may have seemed a logical imperative during the Cold War, but seems far less relevant in facing the more complex challenges of collective security in a Europe characterized by internal disorder and domestic dislocation rather than external threat.” Michael Clarke and Paul Cornish, "The European Defence Project and the Prague Summit,” 780.

103 Helmut Hubel, “The Baltic Sea Subregion after Dual Enlargement,” Cooperation and Conflict: Journal of the Nordic International Studies Association 39:3 (2004): 283. 
defend one of the new members might entail engagement in conflicts that the Allies would hope to avoid, such as the situation in the South Caucasus.

The likelihood of the necessity to take up a self-defense action will be higher if NATO offers membership to countries from unstable regions-e.g. the Western Balkans and the South Caucasus. The biggest problem obviously pertains to Georgia, which still has pending conflicts in South Ossetia and Abkhazia, along with the significant recent complication of Russian incursions. This is why some hold the view that, despite the great strides that have been made in the reform process, Georgia should not be invited to join NATO. Sir Malcolm Rifkind, member of the British Parliament and the former Foreign Secretary (1995-97), argues that the invocation of Article 5 "cannot be considered a hypothetical concern. ... Would it really be wise for NATO member states to accept a legal obligation, not just an option, to come to the aid of Georgia if either or both of these secessionist regimes, with or without the support of Moscow, continued to use armed force against the Georgian government?"104 The same opinion was expressed by other Allied representatives, among them German Chancellor Angela Merkel, who said "countries that are entangled in regional and internal conflicts cannot become NATO members," a statement that clearly referred to Georgia. ${ }^{105}$

A less problematic case is Ukraine, which enjoys relatively secure territorial integrity. However, its relations with the Russian Federation remain tense. Russia has expressed its displeasure about Ukraine's ambitions to join NATO. ${ }^{106}$ When we add the facts that "Ukraine has a large Russian-speaking minority, ... Crimea is an ethnic Russian territory that was only joined to Ukraine in the 1950 s ... and [the fact that] the question of Ukraine's orientation towards the West is the seminal issue of Ukrainian politics, with the population almost equally divided," concerns about the obligations coming from Article 5 are inevitably raised. ${ }^{107}$

\section{Military Contribution}

When discussing NATO enlargement, one of the elements the Allies must take into account is the potential military contribution of prospective members. As noted by Leo Michel, "the so-called 'burdensharing' debate was as old as NATO itself." "108 It relates not only to capacities, but also to readiness to meet commitments as prospective members of a politico-military alliance. This debate was also reflected during the Bucharest

\footnotetext{
${ }^{104}$ Malcolm Rifkind, “NATO Shouldn’t Advance too Far East,” Daily Telegraph (London) (2 April 2008); available at www.telegraph.co.uk/opinion/main.jhtml?xml=/opinion/2008/04/ 02/do0204.xml.

105 Bill Van Auken, “US, Germany Clash over NATO Expansion Plan,” World Socialist Web Site (2 April 2008); available at www.wsws.org/articles/2008/apr2008/nato-a02.shtml.

106 See "Russia Attacks NATO on Enlargement," International Herald Tribune (23 January 2008); available at www.iht.com/articles/2008/01/23/europe/russia.php.

107 Rifkind, “NATO Shouldn’t Advance too Far East.”

${ }^{108}$ Michel, "NATO Decisionmaking: How the 'Consensus Rule’ Works,” 7.
} 
Summit, when the members discussed the question of NATO's engagement in Afghanistan. $^{109}$

When looking at the military capabilities of possible future member states, the conclusion is that they are limited. Most of these states' armed forces are quite small and are still undergoing modernization. The only exception in terms of potential is the Ukrainian military, which has 150,000 troops, in spite of the fact that the country is still conducting a vast security and defense sector reform. ${ }^{110}$ The humble military capacities in these nations stem from the fact that the states of the Western Balkans and the South Caucasus represent small territories and populations, which in consequence brings about relatively modest defense spending and troop levels. The data of eight states currently in the process of integrating with NATO is presented in Table 2 below. These data confirm that the military potential offered by these states is limited.

Table 2: Economic and Military Data for Eight States Currently Integrating with NATO (2007) ${ }^{111}$

\begin{tabular}{lccccc}
\hline Country & $\begin{array}{c}\text { Territory } \\
\left(\mathbf{k m}^{2}\right)\end{array}$ & $\begin{array}{c}\text { Population } \\
(\mathbf{m i l l i o n})\end{array}$ & $\begin{array}{c}\text { Armed } \\
\text { Forces }\end{array}$ & $\begin{array}{c}\text { Defense } \\
\text { spending } \\
(\mathbf{\%} \text { of GDP })\end{array}$ & $\begin{array}{c}\text { Defense } \\
\text { budget }\end{array}$ \\
\hline Albania & 28,748 & 3.6 & 16,000 & 2.00 & USD 208m \\
\hline Croatia & 56,542 & 4.5 & 16,000 & 1.69 & USD 875m \\
\hline Macedonia & 25,333 & 2.0 & 7,900 & 2.30 & USD 161m \\
\hline Georgia & 69,700 & 4.6 & 26,900 & 0.59 & USD 583m \\
\hline Ukraine & 603,700 & 46.3 & 152,000 & 1.33 & USD 1.81bn \\
\hline $\begin{array}{l}\text { Bosnia and } \\
\text { Herzegovin }\end{array}$ & 51,129 & 4.5 & 10,000 & 4.50 & USD 142m \\
\hline Montenegro & 14,026 & 0.7 & 1,600 & 2.04 & EUR 40m \\
\hline Serbia & 77,474 & 8 & 30,000 & 2.50 & USD 1bn \\
\hline
\end{tabular}

${ }^{109}$ Robert D. Kaplan, “NATO Offers Equal Alliance, Unequal Roles,” Der Spiegel Online (27 March 2008); available at www.spiegel.de/international/0,1518,543681,00.html.

${ }^{110}$ Ministry of Defense of Ukraine, White Book 2007, Defense Policy of Ukraine (Kiev, 2008), 110; available at www.mil.gov.ua/files/white_book/white_book_en2007.pdf.

${ }^{111}$ Data compiled from the respective countries' MoD publications, and the CIA World Fact Book, available at https://www.cia.gov/library/publications/the-world-factbook/index.html. 
Similarly, the ten countries that joined NATO in 1999 and 2004 also brought relatively small military contributions to the table, in terms of strengthening NATO's operational capability. ${ }^{112}$ As noted by Jiri Šedivý, "the first wave [of NATO expansion] was driven by the political ambitions of the central Europeans and the political interests of some of NATO core countries (namely the U.S. and Germany). Questions concerning future members' military capacities and capabilities were secondary." over, the previous rounds of enlargement showed that the military adaptation of new members to NATO standards was very problematic. ${ }^{114}$ This led to criticism of the invitation of those countries, both because of their limited military strength and because of problems encountered in the process of modernization of their military after accession (e.g. modernization of equipment, reduction of personnel in the armed forces or low defense spending). ${ }^{115}$

The second dimension of the military contribution to the tasks of NATO is engagement in international operations. Nowadays, the Alliance is extensively involved in missions in different parts of the world, and anticipates significant engagement on the part of aspiring countries in these efforts. ${ }^{116}$ NATO is presently conducting missions in Kosovo (KFOR), Afghanistan (ISAF), Iraq (NTM-I), and the Mediterranean (Active Endeavour). The priority operation for NATO is ISAF. At the same time, this mission is the most difficult in the history of the Alliance. Consequently, this is one of the reasons why NATO faces so many difficulties in generating forces for the needs of ISAF. Having said that, in the process of enlargement NATO expects that newcomers will actively engage in operational tasks. This was explicitly stated during the Riga

${ }^{112}$ The limited contribution of new members has been criticized. See, e.g., Hendrickson, "The Miscalculation of NATO's Death,” 100.

113 Šedivý, "The Puzzle of NATO Enlargement," 3.

${ }^{114}$ Karl-Heinz Kamp, "NATO-Enlargement After the Riga Summit," Analysen and Argumente aus der Konrad-Adenauer-Stiftung 32 (2006): 2.

${ }^{115}$ Zoltan Barany, “NATO Expansion, Round Two: Making Matters Worse,” 127-28. In 2002, Jeffrey Simon conducted a very interesting study of new NATO members (the Czech Republic, Hungary, and Poland). He observed that "the performance of the three newest member states has not been good, and this relatively poor performance has created a problem of credibility that will work to the detriment of the aspirant states.” Moreover, Simon listed "seven specific areas of deficiencies within these states, including: force planning inadequacies; budgetary constraints; restructuring of military personnel; constitutional and legal system inadequacies; national security concepts, defense concepts, and military doctrines; defense planning complications; and declining public support for the military." Chris Donnelly and Jeffrey Simon, "Roadmaps to NATO Accession: Preparing for Membership,” 2002.

${ }^{116}$ The operational burden of the Alliance is supported by Partner nations. As of summer 2007, thirteen of the eighteen non-NATO contributing nations (NNCNs) participating in NATO operations were PfP nations. Nine countries were contributing respectively 2,300 troops to KFOR and 780 to ISAF. Partner nations were also engaged at that time in the operation Active Endeavour in the Mediterranean. See Robert F. Simmons, Jr., "Ten Years of the EuroAtlantic Partnership Council: A Personal Reflection,” NATO Review (Summer 2007); available at www.nato.int/docu/review/2007/issue2/english/art5.html. 
Summit in 2006. The Allies committed to increase "contributions to international peacekeeping and security operations." ${ }^{\text {117 }}$ However, if one assesses the possibility of those countries to contribute to NATO operations with expeditionary forces, it is clear that they do not have much to offer. The armed forces of prospective NATO members are small (except for Ukraine), and their militaries face other major problems that require heavy investment, like defense reform. When one looks at the current engagement of nine countries in supporting NATO's priority mission in Afghanistan, currently only three out of eight aspirant nations have contingents within ISAF. All of them constitute contributions from MAP countries, which are quite limited: there are 210 Croatian, 140 Albanian, and 120 Macedonian troops deployed within the ISAF operation. $^{118}$

However, one cannot rule out the possibility that after its accession a specific state will increase its contribution to NATO-led operations. ${ }^{119}$ Nonetheless, NATO's experience shows rather that the reality is less optimistic. Paradoxically, the Alliance has less influence on the decisions of its members with regard to their operational involvement than it does in the case of aspiring countries. The latter, if they want to join NATO, always try to boost their engagement in missions to prove that they will be reliable partners within the Alliance. ${ }^{120}$

However, the examples of the nations from Eastern, Central, and South East Europe have shown that, despite their limited military and financial potential, they can be viable contributors to NATO operations. This can best be achieved through role specialization. As Missiroli notes, "The Czechs, for example, have focused on developing nuclear, biological and chemical decontamination units; the Hungarians on engineering squads; and the Romanians on mountain light infantry." 121 Aspiring nations are applying the same approach. Small states from the Western Balkans are trying to develop niche capabilities. One of the examples is Albania, which hopes to create "a deployable Rapid Reaction Brigade, ... Special Operations forces, Military Police, explosive ordnance disposal experts, engineers, as well as medical support." ${ }^{122}$

\section{Support for NATO Enlargement}

There is a general recognition among the member states that NATO will continue to expand. The enlargement of the Alliance is still strongly supported by the United

117 NATO, "Riga Summit Declaration,” 2006.

${ }^{118}$ NATO, “International Security Assistance Force,” 1 April 2008; available at www.nato.int/ isaf/docu/epub/pdf/isaf_placemat.pdf.

${ }^{119}$ A good example of this view is Poland, which boosted its engagement in the ISAF operation. Poland "has twice sent in more troops to eastern Afghanistan-first in Fall 2006 when it added 1,000 and then again in this winter with a pledge for 400 more troops and eight vital helicopters.” Daniel Fried, Assistant Secretary of State for European and Eurasian Affairs, "NATO: Enlargement and Effectiveness," 8.

${ }^{120}$ For example, Croatia, as an aspiring country, substantially increased its contribution to the ISAF operation in Afghanistan.

${ }^{121}$ Antonio Missiroli, “Central Europe Between the EU and NATO,” 123-24.

122 Sverre Myrli (rapporteur), “The Three Adriatic Aspirants,” 5. 
States; in April 2007, President George W. Bush signed the "NATO Freedom Consolidation Act of 2007," which reaffirms backing for continued enlargement for such nations as Albania, Croatia, Georgia, Macedonia, and Ukraine.

There has been general support by other NATO members for a round of enlargement that would include the three Western Balkans countries-Albania, Croatia, and Macedonia. However, there are still difficulties in the relationship between Greece as a member state of NATO and Macedonia as an aspirant country over the name of the state of Macedonia. This disagreement brought about a decision at the Bucharest Summit that caused Greece to block the invitation of Macedonia to join NATO. However, it should be underlined that the Greek government is not opposed to the accession of Macedonia to the Alliance as such; from the Greek perspective, the only problem is the name. $^{123}$

The issue over the potential membership of Ukraine and Georgia seems to be more complicated. The membership of those nations in NATO is supported especially by the U.S. and the nine new members of NATO (except for Hungary). On the other hand, there is significant opposition from such nations as Belgium, France, Germany, Greece, Italy, Luxembourg, the Netherlands, Norway, Spain, and Hungary. They are not only against the membership of Georgia and Ukraine in NATO, but are also opposed to granting them MAP status. The listed group of nations is concerned that, by enhancing relations with Georgia and Ukraine, the Alliance may cause further disputes between NATO members and Russia. The ongoing dispute over U.S. plans to deploy elements of a missile defense system in the Czech Republic and Poland exacerbates the Russia problem. Moreover, it may worsen Moscow's already strained relations with Ukraine and Georgia (as mentioned above, Russian relations with Georgia have very recently worsened to the point of armed conflict). This group of NATO members also points to limited support within Ukrainian society for Euro-Atlantic integration. An additional fear pertains to the lack of territorial integrity of Georgia. ${ }^{124}$

Nonetheless, as mentioned above, Ukraine and Georgia can count on backing from NATO members in Eastern and Central Europe. This was apparent in the run-up to the Bucharest Summit, especially in the case of Ukraine. As one observer wrote at the time, "These nations firmly believe that Ukraine is strategically important for European security, and a MAP would promote needed military reform and accelerate European integration. Poland, the Czech Republic, Slovakia and the Baltic States argue that a negative response to Ukraine's ambitions would reverse NATO's 'open door' policy for new members.”" ${ }^{25}$ To show its support, in March 2008 nine Eastern/Central European states and Canada sent a letter to the NATO Secretary-General expressing sup-

${ }^{123}$ Press briefing by NATO Spokesman James Appathurai, 3 April 2008; available at www.nato.int/docu/speech/2008/s080403e.html.

124 “Open Door to Ukraine, Georgia, Say Eastern NATO States,” Agence France-Presse (20 March 2008); available at http://afp.google.com/article/ALeqM5jdZbjHcFjlr6c0anD6wKyp4 08dUw.

125 Adrian J. Erlinger, “Ukraine’s NATO Dilemma,” ISN Security Watch (2 April 2008); available at www.isn.ethz.ch/news/sw/details.cfm?ID=18810. 
port for granting Georgia and Ukraine the MAP. ${ }^{126}$ In the view of those nations, such move would increase stability and security on the continent. ${ }^{127}$

\section{The Russian Factor}

Russia does not feel comfortable with the process of enlargement. ${ }^{128}$ It has opposed every round so far and is still trying to influence decisions in this regard. The Alliance has been for a long time, starting with the first round of expansion after the end of Cold War, moving towards the borders of the Russian Federation. Earlier, during the preparation to the rounds of enlargement in 1999 and 2004, the question was very broadly discussed with the Russian Federation.

At present, the question of NATO enlargement still constitutes a major point of disagreement between the Russian Federation and the Western countries. In addition, there are other issues that complicate relations between the Kremlin and the West. The two primary points of friction are the recognition of the independence of Kosovo by a majority of NATO members, and U.S. plans to deploy missile defense facilities on the territory of the Czech Republic and Poland.

Moscow is not opposed to NATO's expansion to the Western Balkans. But expansion to its two neighbors, Georgia and Ukraine, represents a different matter entirely. The Russian Federation is still opposed to "any further eastward expansion of NATO, particularly into Georgia," and consequently has expressed its objection with regard to the admission of those two states to NATO, even with regard to the possibility of MAP status. ${ }^{129}$ The Russian Federation perceives such an expansion of NATO's reach to its borders as a threat to its security. During the Munich Conference on Security Policy in February 2007, President Vladimir Putin said that "NATO expansion does not have any relation with the modernization of the Alliance itself or with ensuring security in Europe."130 Since then, the Russian President has continued with statements opposing NATO enlargement. In February 2008, he stated "Moscow would regrettably be forced

126 Those nine nations were Bulgaria, the Czech Republic, Estonia, Latvia, Lithuania, Poland, Slovakia, Slovenia, and Romania. The only one from this region that did not sign the letter was Hungary, due to that state's close relations with the Russian Federation (e.g., Hungary recently “signed a draft agreement to join Gazprom's South Stream project in late February”). Ibid.

127 See "10 NATO Countries Back Georgian, Ukrainian Aspirations for Alliance Entry,” Voice of America News (20 March 2008); available at www.voanews.com/english/2008-03-20voa56.cfm.

${ }^{128}$ In the National Security Concept of the Russian Federation (2000) NATO's eastward expansion was defined as one of the fundamental threats (NSC 2000, 4-5).

${ }^{129}$ Peter Finn, “Putin Names Nationalist to NATO,” Washington Post (11 January 2008): A13.

${ }^{130}$ Vladimir Putin, Speech at the 43rd Munich Conference on Security Policy, 2 October 2007; available at www.securityconference.de/konferenzen/rede.php?sprache=en\&id=179. 
to redirect its missiles at its post-Soviet neighbor, if Ukraine went ahead with its plan to join NATO and allowed U.S. infrastructure on its territory."131

Furthermore, in January 2008 President Putin appointed Dmitry Rogozin, “a prominent nationalist and political gadfly" who "has harshly criticized NATO and U.S. policies, including the alliance's eastward expansion," as Russia's new permanent representative to NATO. ${ }^{132}$ The decision was a signal of Russia's determination to stop the process of enlargement. Rogozin himself has expressed his opposition to NATO expansion; in advance of the Bucharest Summit, he stated "Russia 'will not move a millimeter' on the question of opening up for Ukraine and Georgia the Membership Action Plan (MAP) to join NATO."133

The Russian Federation tries to influence the decision-making process within NATO by "using special relations with individual member countries to frustrate collective decisions." ${ }^{34}$ During the Bucharest Summit, Russia succeeded in applying this tactic. The Allies did not invite Georgia and Ukraine to begin the MAP process, thanks to strong opposition from France and Germany in particular, who feared the damage that a decision in favor of Georgia and Ukraine would have done to their respective bilateral relations with the Russian Federation. Shortly after the Bucharest Summit, German Minister of Foreign Affairs Frank-Walter Steinmeier stated, "Russia deserved some compensation at the expense of Ukraine and Georgia, in return for Moscow's presumed 'loss' in Kosovo."135 Additionally, France's foreign minister "suggested that NATO must 'take into account Russia’s sensitivity and the important role it plays' when expanding the alliance."136

NATO itself needs support from the Russian Federation to carry out its tasks. The West needs "Russian cooperation on Afghanistan, Kosovo, Iran, missile defense, arms control, and energy supplies,” according to Charles Kupchan. ${ }^{137}$ This reliance was also reflected during the Bucharest Summit, which saw NATO and Russia sign "a land transit pact allowing the Alliance to deliver non-lethal supplies to troops in Afghanistan

${ }^{131}$ Luke Harding, "Putin Issues Nuclear Threat to Ukraine over Plan to Host US Shield,” The Guardian (U.K.) (13 February 2008); available at www.guardian.co.uk/world/2008/feb/13/ russia.putin.

${ }^{132}$ Finn, "Putin Names Nationalist to NATO."

133 “Russia’s Envoy to NATO Slams Ukraine’s Membership Bid,” Red Orbit (1 April 2008), originally published by Ekho Moskvy radio station (in Russian); available at www.redorbit.com/news/general/1321313/russias_envoy_to_nato_slams_ukraines_members hip_bid/index.html?source=r_general.

${ }^{134}$ A prime example of this tactic was a situation near the time of the Bucharest Summit when "Russian President Vladimir Putin telephoned French President Nicolas Sarkozy to say, 'I don't have a veto, but I have an opinion' on the Ukraine and Georgia decisions.” Vladimir Socor, "The Pro-MAP Faction Succeeds at NATO Summit," Eurasia Daily Monitor (8 April 2008); available at www.jamestown.org/edm/article.php?article_id=2372952.

135 Ibid.

${ }^{136}$ Erlinger, "Ukraine’s NATO Dilemma."

${ }^{137}$ Charles Kupchan, “NATO Divided,” International Herald Tribune (9 April 2008); available at www.iht.com/articles/2008/04/09/opinion/edkupchan.php. 
across Russian territory, but it did not cover troop transport or air transit arrangements as initially sought by NATO." ${ }^{338}$

Despite the view of the Russian Federation, Moscow does not hold a veto within the Alliance, a fact that has been emphasized by both member states and NATO officials. ${ }^{139}$ NATO Secretary-General Jaap de Hoop Scheffer constantly repeats the mantra that "the enlargement of NATO's membership is not directed against any country [and] ... that no country which is not a member of NATO has a veto or 'droit de regard' over NATO enlargement decisions." "Th0 This statement underscores the message that NATO members will always be the ones to make final decisions on enlargement, and that the Russian Federation cannot have a decisive influence on this process.

\section{Decision-making Process}

Decisions in NATO are made by unanimous agreement by all member states. The consensus rule reflects NATO's character as “an alliance of independent and sovereign countries rather than a supranational body. The rule also exemplifies for many the 'one for all, all for one' ethos of the organization's collective defense commitment." "141 The question of the decision-making process has always been taken into account when discussing potential invitations to the organization. ${ }^{142}$ However, it seems that the admission of new members will not significantly complicate the decision-making process.

As Karl-Heinz Kamp argues,

the enlargement opponents' fear that admitting new members would complicate the decision-making process within the Alliance and thus cripple the ability of NATO to act decisively proved to be unfounded. The Alliance reached its most difficult decision to date-air strikes against Belgrade as part of the response to the Kosovo crisis-despite the fact that three countries (Poland, Hungary, and the Czech Republic) had joined the Alliance just days earlier. Problems in reaching consensus in the years since then have primarily arisen from the 'old' NATO member states, and only rarely from the new ones. ${ }^{143}$

In practice, the strongest influence on shaping decisions within NATO has been the prerogative of the largest countries - in terms of wealth, military strength, and population. There is no doubt that the difference in impact upon decisions of the Alliance

${ }^{138}$ Oleg Shchedrov and Mark John, "Putin Tells NATO to 'Be friends'," International Herald Tribune (4 April 2008); available at www.iht.com/articles/reuters/2008/04/04/europe/ OUKWD-UK-NATO.php.

${ }^{139}$ See, e.g., Daniel Fried, Assistant Secretary of State for European and Eurasian Affairs, "NATO: Enlargement and Effectiveness," 11.

${ }^{140}$ Jaap de Hoop Scheffer, Speech at Tbilisi State University, Tbilisi, Georgia, 4 October 2007; available at www.nato.int/docu/speech/2007/s071004a.html.

${ }^{141}$ Michel, “NATO Decisionmaking: How the 'Consensus Rule’ Works,” 3.

${ }^{142}$ The question of the effectiveness of the decision-making process in NATO after the next possible round of enlargement, however, does not stimulate nearly as vivid a discussion as it does in the case of the EU.

${ }^{143}$ Kamp, “NATO-Enlargement After the Riga Summit,” 2. 
between small countries (Luxembourg or Estonia) and the leaders of the organization (the U.S., the U.K., Germany, or France) is extremely wide. Thus, in case of a stalemate, these dominant states are able to prevail over other members of NATO.

It seems that the accession of new nations will not significantly complicate the decision-making processes within the Alliance, and will not undermine their coherence. New members will adapt to NATO's cooperative approach, or they will likely not reach full membership status. Additionally, the capacities of prospective members to challenge decisions made by the largest member states are limited.

\section{Conclusion}

There is no doubt that the process of NATO enlargement has been a success. It has helped to strengthen security and stability in the entire Euro-Atlantic area. Moreover, as NATO officials often emphasize, the process of expansion has helped to reinforce liberty, democracy, the rule of law, and shared values throughout Europe and beyond. ${ }^{144}$

These concepts highlight the character of NATO enlargement nowadays. It is aimed largely at expanding a community of like-minded countries that is willing to pool their military capacities to guarantee their security. Moreover, since the security environment has changed since the end of the Cold War, and the threat of Soviet aggression disappeared (at least for the most part), NATO's expansion is not being directed against any nation. Rather, the rationale for enlargement is to build a security community in the Euro-Atlantic area. Therefore, expansion of NATO can be seen as a political process, instead of a military project.

The process of NATO enlargement will certainly continue. The last Bucharest Summit showed that there will be two additional member states soon (Albania and Croatia), and there are other nations from the Western Balkans, Eastern Europe, and the South Caucasus waiting in line. It seems to be unavoidable that the Alliance will soon be an institution comprising over thirty nations from Europe and North America. One can expect that the next decisions on enlargement will be made during the upcoming NATO Summit in Strasbourg and Kehl in April 2009. However, these decisions will be confined to Macedonia. The greater challenge confronting NATO is how to deal with the two most difficult cases of Georgia and Ukraine. These states currently are seeking to join the MAP process, but their ultimate goal is obviously membership in NATO. Further down the road, the Alliance will have to decide if it is really interested in beginning the debate on possible expansion to new regions in order to embrace a few select contact countries, such as Australia and South Korea. From discussion presented above in this article, one can draw several specific conclusions. They are briefly outlined in the sections below.

144 Jaap de Hoop Scheffer, Opening Remarks at the North Atlantic Council Summit Meeting, 3 April 2008; available at www.nato.int/docu/speech/2008/s080403b.html. 


\section{Continuation of Enlargement}

The basic conclusion to be drawn-significant, if obvious-is that NATO will continue enlarging. The Alliance will follow the logic of expansion that began in the 1990s, and which has been embodied by two waves of enlargement to the nations of Eastern and Central Europe and the Balkans in 1999 and 2004. Therefore, the rhetorical question posed almost fifteen years ago by U.S. President Bill Clinton, and nowadays asked by Jaap de Hoop Scheffer, remains valid: not the question of "if”, but only of "when." 145

One can expect that NATO will grow in the future to a size of over thirty member states. It is quite difficult to precisely predict how many members there will be definitively, but it is expected that there will be twenty-eight nations (including Albania and Croatia) in NATO in 2009. Subsequently, the Alliance will invite other countries from the Western Balkans: Bosnia and Herzegovina, Macedonia, and Montenegro. Georgia and Ukraine will continue to be problematic cases. It seems that those countries will become members of the organization, although their path to membership may be quite bumpy and long.

Kosovo will probably be admitted to the Alliance as well. However, in this case it is an absolute requirement that the internal security situation is stabilized and the state functions well. Last but not least, there is also the question of Serbia. NATO showed its interest in significantly enhancing cooperation with that country. In this case, however, everything depends on the climate of Serbian society and the political establishment itself. They will have to decide on the future of their country's integration into the Euro-Atlantic community.

\section{Enlargement Directed by Political Reasons}

The accession of additional countries to NATO can be perceived as a continuation of the political process of strengthening stability and security in the Euro-Atlantic area, as well as the consolidation of democracy and community based on shared values. Therefore, the driving force behind NATO expansion is still predominantly political. This is something of a paradox, because enlargement of alliances is generally directed at strengthening their military potential. However, this anomaly results from the changed security environment after the end of the Cold War and NATO's adaptation to conduct diverse tasks, such as conducting stabilization operations.

The question of common values and strengthening the community of like-minded states constitutes the basis of the debate on NATO enlargement. As stated by former U.S. Secretary of State Colin Powell in 2004, "For most of its existence, NATO has been concerned mainly with the defense of common territory. NATO is now transformed, as only a league of democracies can be, into an alliance concerned mainly with

${ }^{145}$ Jaap de Hoop Scheffer, Speech at the Albanian Parliament, 6 July 2006; available at www.nato.int/docu/speech/2006/s060706a.htm. 
the defense of common values and common ideas."146 However, one has to keep in mind that the military potential and military preparedness of prospective members, which is objectively limited, will be taken into consideration during any future discussions on enlargement.

\section{Formal Framework of Enlargement}

The formal framework of enlargement still rests on the provisions of the North Atlantic Treaty, mainly Article 10, as well as the Study on NATO Enlargement. Those acts define the guidelines for prospective members of NATO.

Expansion of the Alliance will continue to be a performance-based process. Additionally, the extension of invitations to join NATO will be still a political and case-bycase decision. Nonetheless, as the experience of the two previous rounds of enlargement in 1999 and 2004 showed, NATO does not rigidly stick to those benchmarks. But it should be noted that in the cases of Albania and Croatia-the states that were invited to join the organization during the 2008 Bucharest Summit-both nations met the established standards for membership.

Through various mechanisms of the Partnership for Peace program, NATO helps aspiring nations in their process of integration within the Euro-Atlantic security community. The most important step in this process is the Membership Action Plan. This tool not only helps a nation to conduct a broad process of reforms, but also verifies if a respective country is ready to be admitted to the organization.

\section{No Further "Big Bang”}

One cannot expect any further round of enlargement that will integrate a large number of nations, as was the case in 2004, when seven nations acceded to NATO. In fact, at present we are witnessing the smallest round of NATO enlargement since the end of the Cold War. The Alliance invited only two nations to join in 2008, after two larger waves of expansions which embraced three (1999) and later seven states (2004) respectively.

It seems that another so-called "big bang” is virtually impossible. The Alliance will extend an invitation to one or up to a maximum of three countries during every forthcoming round of enlargement. This is first a product of simple geography: there are a limited number of states that can be taken into account as prospective NATO members, all of which are located in the Western Balkans, Eastern Europe, and the South Caucasus. The second reason for the limitation is that many of these countries face acute problems - including a lack of territorial integrity or strong public opposition-that consequently hamper the pace of integration or can even stop it cold. Subsequently, this fact brings a third reason for the likelihood that future rounds of NATO expansion will take place on a smaller scale: the limited support of the Allies for further expan-

${ }^{146}$ Colin L. Powell, Remarks at the North Atlantic Treaty Organization Accession Lunch, Washington, D.C., 29 March 2004, http://www.state.gov/secretary/former/powell/remarks/ 30893.htm. 
sion, due to the challenges presented by integrating the current prospective member states.

\section{Limited Military Contribution}

The military reinforcement brought to NATO after the accession of further nations will be modest at best. The military capabilities of the current aspiring countries are limited. In the future, if Ukraine is admitted to NATO, it will be the only exception to this rule, as it possesses robust armed forces with several capabilities (such as airlift) that other prospective member nations simply lack.

However, this will simply represent a continuation of the trend that started with the accession of post-communist nations in 1999 and 2004. The military capacities of the countries of Eastern and Central Europe remain relatively limited, although they are certainly more significant than those represented by the Western Balkans nations. Nonetheless, the small military contributions to be made by current prospective members may have an advantage, in that it will be less problematic to integrate the armed forces of those countries with the Alliance.

With regard to the issue of military contribution, the involvement of new nations in NATO-led operations will be particularly important. Today's data show that these states' contribution is limited in terms of the number of troops and provided capabilities, which will not change significantly over time. The main reason is the obviously limited potential of those nations. This is why they will instead try to provide niche capabilities.

It is also interesting to notice that countries that want to be admitted to NATO often boost their involvement in NATO-led operations (like Croatia) to show that they would be committed and staunch members. However, one should bear in mind that limited military capacities do not disqualify nations from membership. The most important criteria for admission to the Alliance are a nation's contribution to the overall enhanced security of the Euro-Atlantic region and its commitment to democracy and the protection of fundamental freedoms. These dual criteria also show that NATO is not a primarily military organization that is simply aimed at pooling as many as possible military capabilities. In the history of NATO, the organization has undertaken only one purely military action (in the Federal Republic of Yugoslavia in 1999).

\section{Historical Importance}

The enlargements of NATO that took place in 1999 and 2004 had prominent symbolic importance. At the time, NATO stressed that its expansion to the countries of the former Warsaw Pact and to states that had constituted part of the Soviet Union marked the end of the Cold War and of collective divisions within Europe. A further round of enlargement to the Adriatic Three will not carry such symbolic weight. Nevertheless, this development will be important, because the expansion of the Alliance will contribute to the process of the consolidation of democracy and the zone of stability in the Western Balkans, which is particularly important in light of the wars in the former Yugoslavia in the 1990s. 
In the long run, however, the accession of Georgia and Ukraine will have the greatest historic importance. In welcoming these two states, NATO would embrace countries that used to be part of the Soviet Union, and that still hold significant strategic and even psychological value for the Russian Federation.

\section{Process of Democratization}

The prospect of NATO membership (alongside that of membership in the EU) is still one of the main incentives (and also levers) for transition states to conduct the farreaching and often painful process of thoroughly reforming its state structures and civil society. These nations are simultaneously attempting to build a democratic political culture and the institutions of a market economy, as well as to normalize relations with their neighbors and address their internal problems. Democratization and modernization of state structures are some of the basic criteria for admission to the Alliance.

Additionally, it should be noted that — as the experience of the past decade showsthe leverage that the Alliance possesses is most effectively applied before a country joins the organization. This is why NATO presses very hard on certain nations in their reform process before they are invited to join the organization. ${ }^{147}$

\section{No Other Real Option of Security Guarantees}

Although the character of NATO and its tasks have changed since the end of the Cold War, the organization remains the institution that is able to provide the most reliable security guarantees to its member states, given the far-reaching provisions of Article 5 of the North Atlantic Treaty. This is a major reason why European states still seek to obtain membership in the Alliance, especially nations from unstable regions or those ones that have difficult or complex relations with their neighbors. This is a major motivation for the aspiring states from the Western Balkans, Eastern Europe, and the South Caucasus.

\section{Role of the United States}

The United States still plays very influential role in the Alliance, and is without any doubt a driving force behind the process of NATO enlargement; in fact, the U.S. is consistently one of the biggest proponents of extending the number of member states. Moreover, the current Bush Administration has advocated for a broad expansion of the Alliance that would embrace not only nations of the Western Balkans, but also former Soviet republics, i.e. Ukraine and Georgia. Those states constitute the two most controversial candidates for NATO membership at present.

For the U.S., the process of NATO enlargement is still aimed at strengthening stability and security in Europe. As President George W. Bush said at the last Bucharest Summit, "NATO's door must remain open to other nations in Europe that share our

${ }^{147}$ Ronald D. Asmus, “A Better Way to Grow NATO,” Washington Post (28 January 2008): A21, www.washingtonpost.com/wp-dyn/content/article/2008/01/27/AR2008012701611.html ?referrer=emailarticlepg. 
love for liberty.”"148 The U.S also places significant importance on the engagement of new members in the operational tasks of NATO, especially involvement in military operations, and support in dealing with new threats and challenges, such as terrorism or international narcotics trafficking.

\section{NATO’s Effectiveness}

As has been discussed above, the number of member states in the Alliance will continue to increase; at some point in the future there will be over thirty nations in NATO. This is why the Alliance takes into account the influence of enlargement on its effectiveness as it makes decisions about expansion. Enlargement will certainly influence the pace and effectiveness of NATO's decision-making process, especially if the consensus rule will still hold sway. However, it seems that the increase in the number of members will not significantly hamper the efficiency of the Alliance, nor will it undermine its cohesion. The main argument is that newcomers will try to support the implementation of NATO tasks in a constructive way. They will also attempt to prove that they deserve to be members of the Alliance, which will reinforce their constructive attitude within NATO. The only remaining question concerns how significant a role new members can actually play within the Alliance, and how much they are able to influence the collective decision-making process to pursue their own goals.

\section{Role of the Russian Federation}

Russia will still attempt to influence the process of NATO enlargement, even though it is not a member of the organization and holds no veto over the decisions of the Alliance. Additionally, the Russian Federation will try to capitalize on (and at times aggravate) differences between member states for its own purposes. In the same way, Moscow will also exploit problematic issues in its bilateral relations with specific NATO members to gain certain benefits or exert international leverage, as in the recent case concerning the U.S. deployment of a missile defense system in Eastern Europe.

The Russian Federation has expressed its most vocal opposition to eastward NATO enlargement, specifically concerning Ukraine and Georgia. These nations' possible accession to NATO membership, and even steps that represent a strengthening of their cooperation with NATO, will certainly affect Western relations with the Russian Federation. Nonetheless, the final decision on admitting a particular state remains in the hands of the Alliance itself.

\section{NATO’s Partnership Policy}

NATO enlargement will influence the Alliance's partnership policy, particularly cooperation within the framework of the Partnership for Peace. First, the growing number of NATO members will obviously result in a decrease in the number of nations participating in the PfP. Second, the number of Partner nations that are genuinely motivated to strengthen the level of their politico-military cooperation with NATO will decline. Subsequently, the enlargement process will have an increasingly strong impact on the

${ }^{148}$ Brunnstrom and Cornwell, “NATO Agrees Former Soviet Republics Will One Day Enter.” 
quality of relations between the Alliance and Partner nations. Those two effects will represent a continuation of the process that began in 1999 when the first wave of postCold War NATO expansion occurred.

The diminishing importance and quality of cooperation in the PfP program will encourage NATO to devote more time and means to cooperation with its partner nations in other mechanisms, such as contact countries and members of MD and ICI. This tendency will be reinforced by the fact that NATO will increasingly be engaging in operations in different and remote areas of the world. In this light, relations with the contact countries will be of particular importance, since these nations share the same values and strongly support the Alliance in its operations. The strengthening of these forms of partnership will potentially rekindle the discussion on global partnership within NATO.

The concept of the creation of a Europe whole and free, united in peace, democracy, and common values is still of crucial importance. One of the key elements of the implementation of this vision is the process of NATO enlargement. The Alliance will continue to expand in the coming years, taking on board countries that began their process of democratization in the 1990s. The process of integration with NATO in itself will continue to be valuable, and will bring greater stability and predictability on the international scene. Aspiring member countries will continue their process of politico-military transformation in order to meet the benchmarks established by NATO. From their perspective, joining the Alliance is still viewed primarily through the lens of the reliable security guarantees set forth in Article 5 of the North Atlantic Treaty. However, the character and tasks of NATO have evolved since the end of the Cold War, and the Alliance is currently deeply engaged in stabilization tasks as its main effort to enhance global security.

The vision of free and peaceful world has always been important for NATO, and the process of expanding the membership of the Alliance supports the implementation of this concept. In the future, members of the organization will have to address the question of the limits of enlargement. Observers will watch with great interest to see if expansion to the Western Balkans, Eastern Europe, and the South Caucasus ends the chapter of NATO expansion, or if the organization will enlarge still further, perhaps even beyond the Euro-Atlantic region. In this context, there will be also a need to gauge whether enlargement strengthens the Alliance and stabilizes the Euro-Atlantic area, or if it brings about more challenges and risks. The answer to those questions will without question shape the future of NATO. 


\section{Bibliography}

Andreatta, Philippo. "Theory and the European Union's International Relations." In International Relations and the European Union. Oxford: Oxford University Press, 2003.

Glaser, Charles L.. "Why NATO Is Still Best: Future Security Arrangements for Europe." International Security 18, no. 1 (1993).

Goldgeier, James M.. Not Whether But When: The U.S. Decision to Enlarge NATO. Washington, D.C.: Brookings Institute Press, 1999.

Heindel, Richard H., Thorsten V. Kalijarvi, and Francis O. Wilcox. "The North Atlantic Treaty in the United States Senate." The American Journal of International Law 43 (1949).

Hodge, Carl C.. NATO for a New Century: Atlanticism and European Security . Westport, CT: Praeger Publishers, 2002.

Piccoli, Wolfango. "Alliance Theory: The Case of Turkey and Israel." In CIAO Working Papers ., 1999.

Smith, Mark. NATO Enlargement during the Cold War: Strategy and System in the Western Alliance . Houndmills, U.K.: Palgrave, 2003.

Walt, Stephen M.. The Origins of Alliances . Ithaca, NY: Cornell University Press, 1990. 